\title{
The development of traffic competences - do children need special infrastructure to be safe in traffic?
}

\author{
B. Schützhofer ${ }^{a}$, J. Rauch ${ }^{b}$, J. Stark ${ }^{c}$ \\ ${ }^{a}$ sicher unterwegs - Verkehrspsychologische Untersuchungen GmbH \\ ${ }^{b}$ Allgemeine Unfallversicherungsanstalt AUVA \\ 'University for Natural Resources and Life Sciences Vienna, Institute for Transport Studies \\ Corresponding author:b.schuetzhofer@sicherunterwegs.at
}

ABSTRACT: Alot of (visual, auditory, social, emotional, psycho-motoric, intellectual and cognitive) competences are needed for safe traffic participation. Traffic competences develop during childhood and youth and there is a close relationship to brain maturity. Based on extensive literature analysis a comprehensive tabulation of empirically based developmental milestones was developed by gathering knowledge from different disciplines (Schützhofer, Rauch, Knessl \& Uhr, 2015, Schützhofer, 2017).

These milestones of traffic competences, forming the core of this paper, are now extended and updated to answer the question of how children can be aware of the traffic environment at a certain age and what this implies for their safe traffic participation. This article forms the framework for the tabulation and focuses on the development of visual competences and hazard perception. Based on the results of the literature review, it will be discussed if there are implications for infrastructure planning as well as for traffic education. Main objective of this research is the development of recommendations for age dependent safe traffic participation that do not under- or overstrain children and give them the chance to have their own active traffic experiences within adequate and safe borders.

This traffic psychological and developmental psychological knowledge is essential in various fields. The results address policymakers, traffic managers, transport planners and technicians and help them to appreciate that children are not small adults and adaptions of the existing traffic environment are needed. They can also be a starting point for the development of traffic safety workshops for pedagogues, parents and police officers as in Austria.

KEYWORDS: Development of traffic competences; traffic education; traffic infrastructure for children; hexagon of traffic safety work; traffic sense

\section{INTRODUCTION}

Children are not small adults. Their necessary competences to be safe in traffic are still in development. Empirical findings show, that the perception of the traffic environment strongly depends on the developmental stage of the child (cf table 1). An important target of traffic and mobility education is to train children age-adequate and to help them take the first steps in traffic within safe borders that do not lead to over- or understraining. High-quality programs on traffic and mobility education therefore have to be theory-based and need continuous evaluation. Furthermore, good programs are well structured and build on each other considering that traffic and mobility education are lifelong processes. Thus, they need to begin early in kindergarten and last as long as possible. In the sense of mobility education, programs should continually include aspects promoting children's active and independent mobility by reflecting on the consequences of travel behavior on health and environment; this is not elaborated in this paper. According to the development of the cognitive ability of abstract thinking, good programs start with simple and concrete tasks that become slowly more complex and abstract. Also, according to this mentioned development of abstract thinking the first steps have to be made in the playroom, followed by the protective space. The last important step is the training in a real-life environment. Therefore, besides education and training, infrastructure plays an essential role for safe traffic participation of children.

\section{THEORETICAL BACKGROUND}

As argued in section 2.1, traffic safety work is more successful when it follows an interdisciplinary ap- 
proach, a holistic understanding of traffic behavior and use of infrastructure. Safe traffic participation not only needs a lot of developed single competences, these single competences also must interplay fast and correctly (Schützhofer, 2017, Schützhofer, Rauch, Knessl \& Uhr, 2015). Table 1 shows all necessary competences for safe traffic behavior of children in their development from age 3 to age 14 (cf section 2.2). Due to space constraints in this article the examples focus on visual competences and hazard perception.

\subsection{Interdisciplinary traffic safety work}

Traffic safety and mobility work often focuses on children and pedagogues in kindergarten or school. Sometimes parents are also involved. Because traffic participation takes place in the traffic system, it is necessary to take the whole traffic system into account, including infrastructure, traffic laws etc. and to think in a holistic and interdisciplinary way (Schützhofer et al., 2015).

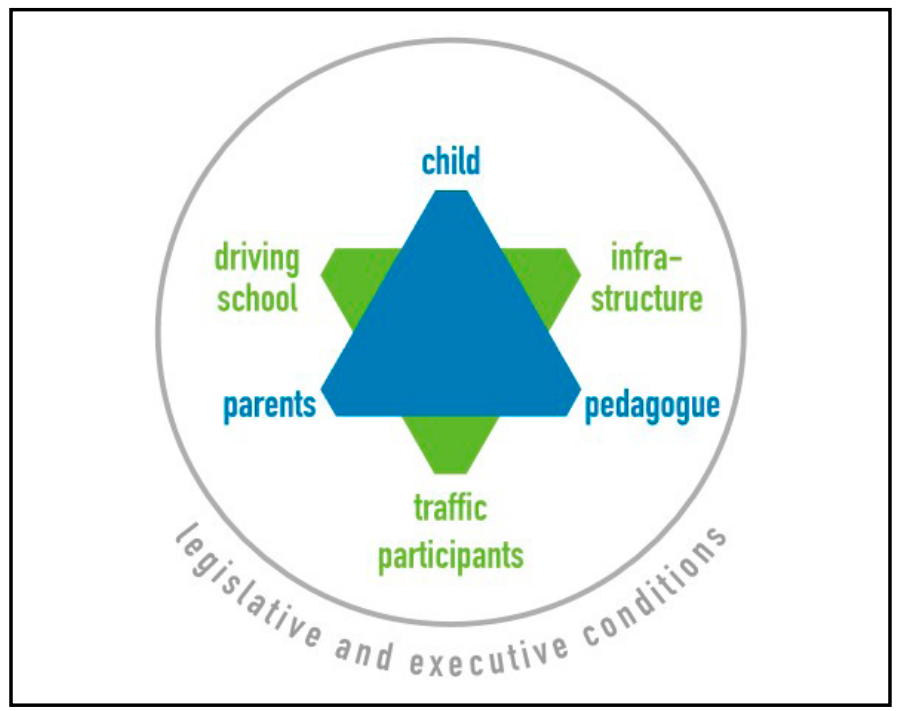

Figure 1: Hexagon of traffic safety work

As shown in figure 1, the pedagogic triangle (child - parents - pedagogue) was extended by another triangle consisting of infrastructure, other traffic participants (e.g. as role models for correct traffic behavior) and driving schools (e.g. as institutions for traffic education for adults). The two triangles are embedded in the actual legislative and executive legal framework. The more child adequate the single dimensions of the hexagon of traffic-safety-work are implemented in the traffic system the more active traffic participation of children can be observed. The safer the given infrastructure is evaluated by the parents the more children are allowed to participate actively and to walk unaccompanied in traffic (Frauendienst \& Redecker, 2011, Ausserer, Röhsner \& Risser, 2010). Schützhofer et al. (2016) therefore recommend checking if guidelines and regulations for traffic planners are child adequate. Traffic psychologists can here contribute with the necessary knowledge and background information and help with further education.

In Austria, for example, there are RVS guidelines for a safe school environment (RVS 03.04.14, 2003) and for child-friendly mobility (RVS 03.04.13, 2015). RVS guidelines are activity regulations with a recommended character representing the current technical standard for a defined field of action. They are based on legal, normative and further technical rules. The school environment in the RVS guidelines is defined as a radius of $250 \mathrm{~m}$ around the school entrance. For the broader environment the implementation of school way plans is recommended. The aim of these guidelines is the adaption of the traffic environment around schools to the needs of children. They contain a list of ratings of specific traffic-organizational and constructional measures. Besides an improvement of traffic safety, the creation of an attractive residential area is considered. Essential for technicians is also the improvement of the visibility conditions. General recommendations for measurements are pedestrian zones in front of schools, enough space in front of the school entrance or bus stops to avoid crowding, speed limits near schools, bicycle lanes, pedestrian crossings that reflect the special needs of children (cf Leden, Johansson, Rosander, Gitelman, \& Gårder, 2018), kiss and go areas, and barrier free design. School way safety and traffic safety of children in general are also an important issue in the traffic safety program of the Austrian Federal Ministry of Transport, Innovation and Technology (bmvit) (bmvit, 2016).

An evaluated good practice example for an interdisciplinary approach for improving traffic safety of children is the so-called school way plans in Austria (Knowles, Schneider \& Robatsch, 2016). They are developed involving children, parents, school directors, police officers, a representative of the road maintenance department and traffic safety experts. The school way plan helps parents to find the safest way to school and to detect any possible dangerous situations. The plans support the local authorities in a further step to decrease or eliminate hazards on the way to school. The school way plans are a good basis for the school way training. 
Children focus on different aspects of the traffic and built environment than adults do

(Limbourg, 2008). For example, in an Austrian study, children's perceptions on the environment were collected with a smartphone application (Stark et al., 2018b). Children locate aspects in their environment that they like or dislike. More than 450 evaluations were collected and visualized in a digital map containing photos and descriptions. A categorization of their observations reveals that children focus not so much on traffic safety issues but rather on functionality aspects like (not) enough space, places to sit, waiting times or damaged local infrastructure as well as on aesthetics like for example cleanliness and roadside greenery (Figure 2). They also take notice of environmental related aspects like air quality and noise emissions in their areas of activity in the city of Vienna. They often take the traffic environment as granted and do not dare to express their wishes. Traffic infrastructure should therefore be planned and build carefully, in a way that attracts the child's attention.

\subsection{Development of traffic competences - developmental milestones by means of visual competences and hazard perception}

As outlined before, traffic competences develop during childhood and adolescence. In Table 1, developmental milestones of average children and their implications for safe traffic behavior are described. This takes into account that some children develop at a slower or faster rate. To use the developed competences effectively in traffic, children need age-specific traffic education and training. Without such education, the necessary traffic understanding is missing. Figure 3 demonstrates, as an example, why this is es- sential by means of visual competences of a 6-yearold pupil. The first photo on the left-hand side shows a typical traffic situation: A father wants to cross the street together with his six-year-old daughter. The second and third photos demonstrate that both have a completely different perspective of the situation: The adult can get a good overview resulting in a reliable information basis for safe traffic behavior. However, the child can only get an overview of parts of the situation and cannot get all relevant details for a safe crossing decision.

Adults need to be aware of these facts when doing traffic education with children. In addition, transport planners have to take the smaller size and the lower eye position into account. Due to their smaller size children don't see the same as adults. When adults are not aware of this fact, they explain traffic relevant details that the children cannot understand because they don't see them. The child in figure 3 would have to move closer to the street or even walk onto the street to have the possibility of a full overview.

In addition to the handicap due to smaller size, depth perception and near and far accommodation are not fully developed until the age of nine. Depth perception and near and far accommodation are necessary requirements for speed and distance perception. Children up to the age of nine are therefore not able to estimate speed and distances in a satisfactory way. They compensate for this lack by interpreting light intensity for distance perception. In their speed rating bright colored cars are both faster and nearer then dark colored cars. This misinterpretation can lead to dangerous situations in traffic and must be considered. Additionally, peripheral vision must be developed during childhood and adolescence. There are different empirical findings concerning this ability, but what is

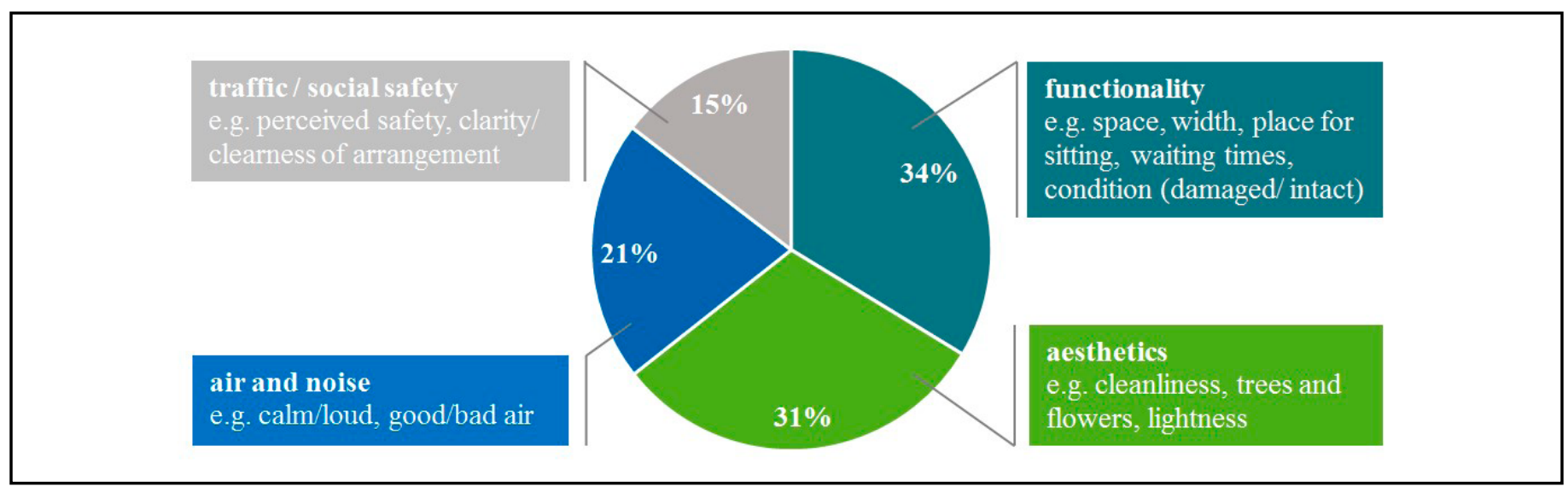

Figure 2: Categorization of aspects of traffic and built environment children evaluated with the help of a smartphone application $(\mathrm{N}=466)$ 

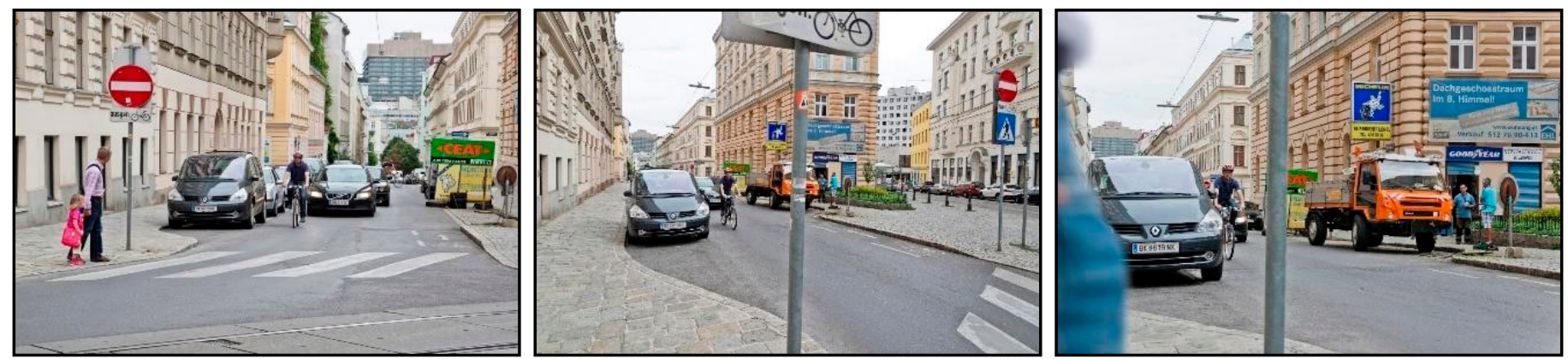

Figure 3: An example of a typical traffic situation (left), adult perspective (middle), child perspective (right) (picture credits: AUVA)

known for sure is that even teenagers cannot use their peripheral vision efficiently (cf table 1 ).

Hazard perception is one of the most important abilities for safe traffic behavior. It is strongly connected with the development of cognitive abilities. Children up to the age of 6 have a preoperational thinking structure. Children from 6 to 12 have a concrete-operational thinking structure (Piaget, 1983). This means that they are not capable of abstract and anticipatory thinking processes. These processes are still in development. In this context it is very important that knowledge should not to be equated with understanding. Many studies have shown that children in kindergarten and in primary school had good results when they were shown pictures of traffic situations and were asked to identify what was dangerous. But when they showed them the same pictures and asked them what they could see, they mentioned numerous traffic irrelevant details before they talked about the traffic relevant ones (Limbourg \& Günther, 1977 citied after Limbourg, 2008, Hill, Lewis \& Dunbar, 2000). When children were asked if something can become dangerous in the situations shown here, especially the younger children failed completely but even the older ones didn't get good results. That's because the cognitive processes necessary for anticipating are not developed in these age groups. This means that hazard perception and hazard awareness are not fully developed until the age of ten.

Compared with adults, children have slower perception, thinking and decision processes. An awareness of hazard perception develops in three developmental stages (Limbourg, 2008, cf figure 4). Pre-school children do not have a realistic sense of hazards in traffic. They have an egocentric view of the world and magic thinking which means that they confuse reality and fantasy. Three, four or five-yearold children feed their dolls or teddys and want to put big Lego figures into a small toy car. They have the same thinking structure in traffic. For example, they believe they are super(wo)man and cars cannot harm them - that's the logical conclusion from a child's perspective. At the age of six, children switch from the pre-operational thinking structure to the con-

- Preventive behavior is used consciously (at the age of 9 to 10$)$.

- Hazardous behavior patterns can be identified in advance but it's still not possible to avoid hazards (at the age of 8 on average). 
crete-operational one. They can now already identify a hazard but only when they are confronted with it and are in the middle of a dangerous situation. This means that a child at the age of six realizes the danger when it's already too late to cope with the situation. The child cycles, for example, downhill and identifies the hazard when it's already too late for braking. It cannot realize that cycling downhill could lead to dangerous speeding. At the age of 8 on average, children can realize this in advance, but preventative behavior is not used consciously until the age of 9 to 10 . Then the child can choose an alternative route and doesn't cycle downhill, for example.

\section{IMPLICATIONS FOR CITY AND TRANSPORT PLANNERS}

From a child's perspective, the public space is not only a space in which to move, but is also a space to live, to meet and to play. It should be pointed out that children want to explore their environment actively. They clearly rate walking as well as the use of a bicycle or scooter as their favorite travel modes (Stark et al., 2018a). Knowledge of children's different perception of the traffic environment should not lead to restrictions to their active and independent mobility. Moreover, the idiosyncrasies of children due to developmental processes should be considered in infrastructure planning. In particular, the design and dimensions of traffic areas must be adapted to children's requirements and abilities. Thus, ideally, public space should be designed in such a way that persons with not fully developed traffic competences can fulfill their mobility needs at the best possible rate. In this respect, it could be unreliable to relate recommendations to specific age classes. It may be better to strive for child-friendly traffic environments using a low as possible stage of development as a yardstick. The following recommendations are based on what is actually seen or perceived through the eyes of a child. No claim is made that this is a complete list, but it should provide examples of implications for city and transport planners.

Generously sized sidewalks extended into the road in special areas help to give an improved overview. A better overview is also given when vision is not obstructed by (large) cars, advertising hoardings, large plants, etc. at junctions, (zebra) crossings or near schools (cf figure 3). In this regard, a careful revision of existing guidelines is recommended, for example regarding adequate clearance gauge requirements. Due to the longer time demands of children e.g. for gap choices, large-scale speed reduction measurements like speed limits or speed bumps for motorized transport and pedestrian islands are as helpful for children as longer green signal phases on traffic lights. As mentioned before, speed reductions should be accompanied by measures on road alignment such as roadway swiveling.

Other organizational measures such as pedestrian zones or temporary car-free zones around schools at the beginning and end of lessons are recommended. Parents escorting their child to school by car should not be allowed to drive close to the school building (kiss and go). This should also refer to teaching staff except for disabled persons. In this regard, as one example, the City of Bregenz (province Vorarlberg, Austria) can be mentioned. In the vicinity of a school strict restrictions have been implemented for safe and active travel for children. Traffic bans for motorized transport (except for residents and suppliers) apply from 07:15 a.m. to 5 p.m. on working days. Bus and tram stops as well as spacious bicycle stands are sited close to the school; parking spaces are limited. In addition, job tickets for public transport and incentives for active mobility are offered for the teachers. There are also other individual examples that have already been implemented in some Austrian provinces (Salzburg, Styria). As a pilot test, also Vienna is going to implement a temporary driving ban starting in September 2018 at one school between 07:45 to 08:15 a.m.

Another very important issue is the logical structure of infrastructure. For the child's better understanding bicycle lanes, for example, must not only be clearly marked but also continuously. When they are interrupted by a junction the child doesn't know how to go on. Children need a logical (at best self-explaining) structure for safe orientation in the traffic system.

It should be pointed out, that residents and parents should be involved when implementing measures in the school environment to enhance the acceptance of regulations.

\section{CONCLUSION AND DISCUSSION}

Depending on age, children don't have the full set of necessary traffic competences or it is not fully developed (cf table 1). Due to these facts they need more time in traffic situations for perception, getting an 
overview, information processing, making decisions (e.g. gap-choices) and starting actions (e.g. crossing the street or starting to cycle). Especially due to children's longer time demand and their smaller size infrastructure that is ideal for adults isn't always the optimum for children. Interdisciplinary traffic safety work can help to find the optimum traffic environment for all users. As described before, the development of school way plans in Austria is a good practice example. School way plans need regular reworking and should be accompanied by effective and determined awareness programs for parents. However, if hazard zones are identified, every effort must be made to improve the built environment in terms of traffic safety.

As outlined before, existing guidelines for a safe school environment and for child-friendly mobility in Austria (RVS) are good practice examples for inclusive urban planning and are a first step in raising awareness regarding children's requirements. These guidelines should also be considered for the immediate catchment area of kindergartens. It should be noted that practical implementations based on such regulations need to be evaluated carefully. In a next step such regulations should be transformed into more binding legal instruments.

It can also be concluded that it is necessary to make adults aware of the child's age dependent traffic competences. This would help to sensitize road users to this vulnerable group so that they are able to understand and appreciate exactly how children may react and the reasons why. In this context, Table 1 can serve as a basis because it gives a comprehensive overview especially concerning single competences. For safe traffic behavior a fast and correct interplay between the numerous single competences is essential. However, single competences develop at different speeds. As such, it is necessary to have a holistic and systemic approach and to investigate how theory based and age specific traffic education as well as child adequate infrastructure can help to compensate for the missing single competences. A lot of research is already done, but further research is still needed especially with an interdisciplinary approach. This research could also be fruitful for a better understanding of self-explaining infrastructure, the redundancy of existing traffic signs or the need for new helpful signs or signals.

To sum up, depending on the local structural conditions special infrastructure for children may be necessary. Child adapted infrastructure helps to improve traffic safety of children and enables them, for example, to perceive all the relevant details to make a safe crossing decision. As a positive side effect, a child adapted infrastructure often tends to make traffic conditions also safer for people with special needs such as the disabled, wheelchair users and the elderly.

\section{REFERENCES:}

Ausserer, K., Röhsner, U. \& Risser, R. (2010). Zufußgehen beginnt im Kindesalter, Wege zum und vom Kindergarten - Endbericht. Gefördert vom BMVIT. http://factum.at/PDFuDoc/ EndberichtGEMMA.pdf (letzter Zugriff 06.07.2018).

Frauendienst, B. \& Redecker, A. (2011). Die Veränderung der selbständigen Mobilität von Kindern zwischen 1990 und 2010. Zeitschrift für Verkehrssicherheit, 4, 187-190.

Hill, R., Lewis, V. \& Dunbar, G.L. (2000). Young children's concepts of danger. British Journal of Developmental Psychology, 18, 103-119.

Leden, L., Johansson, C., Rosander, P., Gitelman, V. \& Gårder, P. (2018). Design of crosswalks for children. A synthesis of best practice. Transactions on Transport Sciences, 9(1), 20-33. doi: https://doi.org/10.5507/tots.2018.004.

Limbourg, M. \& Günther, R. (1977). Erleben und Verhalten von 4- bis 9-jährigen Kindern im Straßenverkehr. Zeitschrift für Verkehrserziehung, 1. 3-9.

Limbourg, M. (2008). Kinder unterwegs im Straßenverkehr. Prävention in NRW 12. Düsseldorf: Unfallkasse Nordrhein Westfalen.

Knowles, D., Schneider, F. \& Robatsch, K. (2016). Schulwegpläne zur Erhöhung der Schulwegsicherheit. Zeitschrift für Verkehrsrecht, 404-412.

Österreichisches Verkehrssicherheitsprogramm VSP 2011-2010. Wien: bmvit - Bundesministerium für Verkehr, Innovation und Technologie 2016.

Piaget, J. (1983). Meine Theorie der geistigen Entwicklung. Frankfurt: Fischer-Verlag.

RVS 03.04.14 (6/2003): Nichtmotorisierter Verkehr, Gestaltung des Schulumfeldes. Wien: Österreichische Forschungsgesellschaft Straße, Schiene, Verkehr (FSV).

RVS 03.04.13 (11/2015): Kinderfreundliche Mobilität. Wien: Österreichische Forschungsgesellschaft Straße, Schiene, Verkehr (FSV).

Schützhofer, B., Rauch, J., Knessl, G. \& Uhr, A. (2015). Neue Ansätze in der verkehrspsychologischen Verkehrssicherheitsarbeit im Kindesalter. Zeitschrift für Verkehrssicherheit, 4, 61, 235-246.

Schützhofer, B., Rauch, J., Uhr, A., Bergmeier, A., Knessl, G. \& Schürch, B. (2016). Verkehrspsychologische und -pädagogische best-practice Empfehlungen für sichere Verkehrsteilnahme als Rad fahrendes Kind. Zeitschrift für Verkehrssicherheit, 4, 153-162. 
Schützhofer, B. (2017). Verkehrsreife - Theoretische Fundierung, Entwicklung und Erprobung der Testbatterie zur Erfassung der Verkehrsreife TBVR 14+. Bonn: Kirschbaum Verlag $\mathrm{GmbH}$.

Stark, J., Meschik, M., Singleton, P. A., \& Schützhofer, B. (2018a). Active school travel, attitudes and psychological well-being of children. Transportation Research Part F: Traffic Psychology and Behaviour, 56, 453-465. doi: https://doi. org/10.1016/j.trf.2018.05.007.

Stark, J., Uhlmann, T., Fanninger, C., Schützhofer, B., Berger, W. \& Kirchner, M. (2018b). Seeing the world through the eyes of a child: A smartphone application to visualize children's perceptions of their transport geographies. Poster presentation on the $9^{\text {th }}$ Child in the City World Conference, $24^{\text {th }}$ to $26^{\text {th }}$ of September 2018 in Vienna, Austria. 


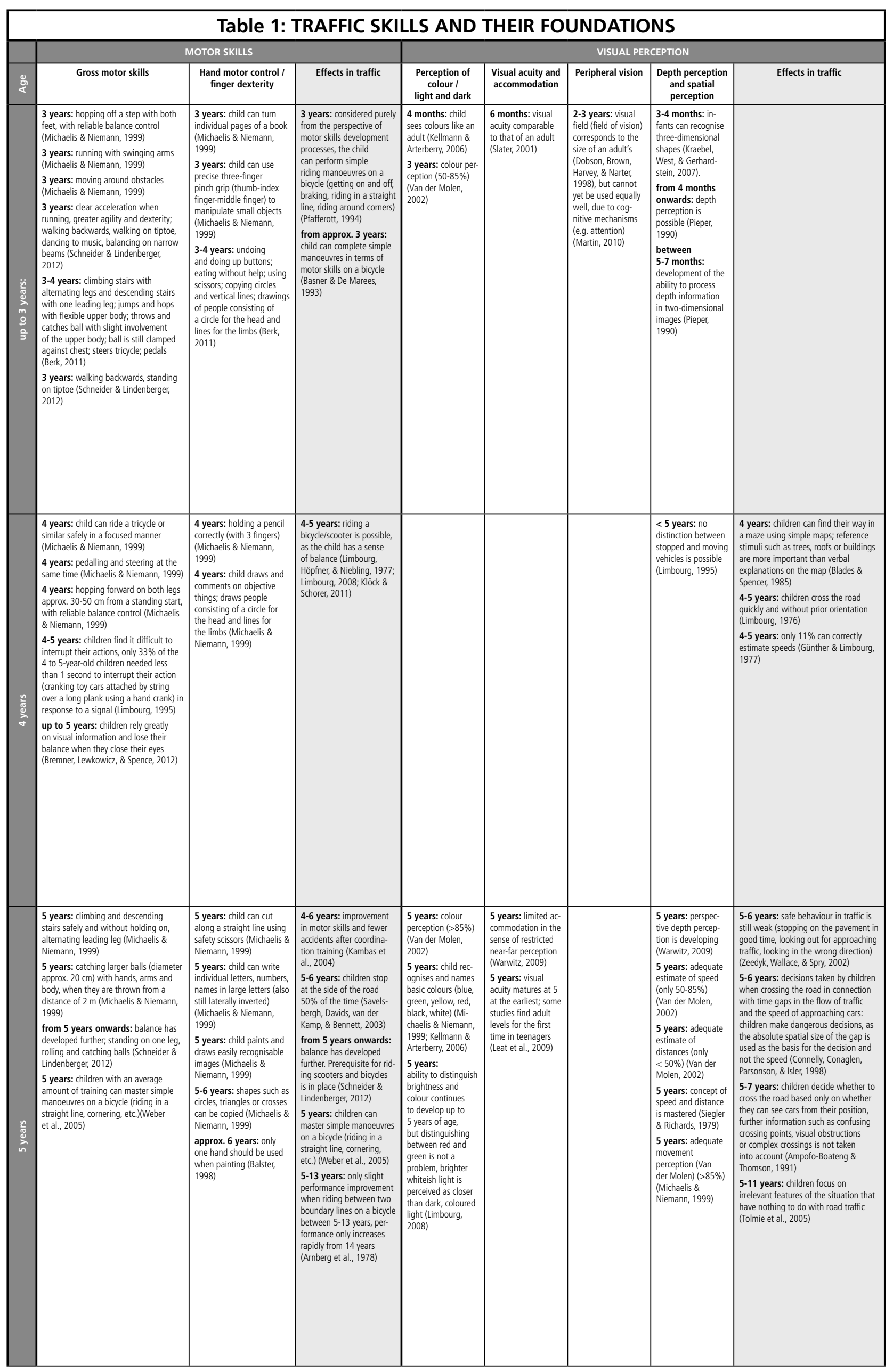




\begin{tabular}{|c|c|c|c|c|c|c|c|c|}
\hline \multicolumn{9}{|c|}{ Table 1: TRAFFIC SKILLS AND THEIR FOUNDATIONS } \\
\hline & \multicolumn{2}{|c|}{ ACOUSTIC PERCEPTION } & \multicolumn{6}{|c|}{ COGNITIVE DEVELOPMENT } \\
\hline ๕ & $\begin{array}{c}\text { General hearing } \\
\text { ability, directional } \\
\text { hearing and noise } \\
\text { differentiation }\end{array}$ & Effects in traffic & $\begin{array}{l}\text { Attentiveness (selec- } \\
\text { tive, duration, divided, } \\
\text { distractibility) }\end{array}$ & $\begin{array}{l}\text { Ability to adopt other } \\
\text { perspectives }\end{array}$ & Thinking & $\begin{array}{c}\text { Social and emotional } \\
\text { competence }\end{array}$ & Hazard perception & Effects in traffic \\
\hline & $\begin{array}{l}6 \text { months: threshold } \\
\text { values for general } \\
\text { hearing ability are } \\
\text { reached at approx. } \\
6 \text { months (Tharpe \& } \\
\text { Ashmead, 2001) } \\
\text { 3-4 years: hearing } \\
\text { ability reduced by } \\
7-10 \text { decibels (cars } \\
\text { heard later) (Pieper, } \\
\text { 1990) }\end{array}$ & & $\begin{array}{l}\text { 2-6 years: selective } \\
\text { attention develops slowly } \\
\text { in the first } 2 \text { years of life, } \\
\text { with significant develop- } \\
\text { mental gains up to approx. } \\
\text { the 6th year of life (Garon, } \\
\text { Bryson, \& Smith, 2008) } \\
3 \text { years: child plays in } \\
\text { a focused and in-depth } \\
\text { manner: "make believe" } \\
\text { games, games with cars, } \\
\text { dolls, building blocks, } \\
\text { Playmobili, etc. (Michaelis } \\
\text { \& Niemann, 1999) } \\
\text { up to approx. } 4 \text { years: } \\
\text { attention is exclusively } \\
\text { controlled by environ- } \\
\text { mental stimuli. Children } \\
\text { are hardly able to pay } \\
\text { attention in the manner } \\
\text { necessary for their safety } \\
\text { (Limbourg, 1995) }\end{array}$ & $\begin{array}{l}\text { 3-6 years: egocentric } \\
\text { adoption of perspective } \\
\text { in the sense of "I see } \\
\text { the car, therefore the car } \\
\text { sees me!"; differences } \\
\text { between him//herself and } \\
\text { others are perceived, but } \\
\text { not differences to his/her } \\
\text { own social perspective } \\
\text { (Piaget, 1983) } \\
\text { 3-7 years: stage of } \\
\text { subjective interests } \\
\text { (Warwitz, 2009) }\end{array}$ & $\begin{array}{l}\text { 2-6 years: pre-operational } \\
\text { stage (Piaget, 1983) } \\
\text { 2-4 years: descriptive-situ- } \\
\text { ational and causal thinking } \\
\text { (an event has a cause), } \\
\text { self-centred perception and } \\
\text { thinking. Egocentrism is based } \\
\text { on the reactions of adults } \\
\text { (Böttcher, 2005) }\end{array}$ & $\begin{array}{l}\text { 2-4 years: impulsive and } \\
\text { need-based actions take } \\
\text { place without fine control } \\
\text { and without insight into } \\
\text { social rules (Böttcher, } \\
\text { 2005) } \\
\mathbf{3} \text { years: playing together } \\
\text { with other children for at } \\
\text { least } 5 \text { minutes (Michaelis } \\
\text { \& Niemann, 1999) } \\
\mathbf{3} \text { years: child can stay } \\
\text { with people known to } \\
\text { him/her for several hours, } \\
\text { and also stay outside the } \\
\text { house without a caregiver } \\
\text { (Michaelis \& Niemann, } \\
\text { 1999) } \\
\mathbf{3} \text { years: imitates adult } \\
\text { activities in role play; would } \\
\text { like to help with household } \\
\text { activities (Michaelis \& } \\
\text { Niemann, 1999) }\end{array}$ & $\begin{array}{l}\text { 3-4 years: only very vague } \\
\text { basic understanding that traf- } \\
\text { fic an be dangerous (Briem \& } \\
\text { Bengtsson, 2000) }\end{array}$ & $\begin{array}{l}\text { 3-4 years: only very vague basic } \\
\text { understanding that traffic can } \\
\text { be dangerous; children only had } \\
\text { dolls use the zebra crossing by } \\
\text { chance, and hardly looked and } \\
\text { waited before they crossed the } \\
\text { road (Briem \& Bengtsson, 2000) } \\
\text { 3-7 years: children are often } \\
\text { emotionally engaged in the } \\
\text { process of riding a bicycle. Mixing } \\
\text { of reality and fantassy, bicycle is } \\
\text { viewed as a horse for example. } \\
\text { This leads to distraction and } \\
\text { poor hazard perception (Walter, } \\
\text { Achermann Stürmer, Scaramuzza, } \\
\text { Niemann, \& Cavegn, 2012) }\end{array}$ \\
\hline & $\begin{array}{l}\text { 4-5 years: acoustic } \\
\text { perception/location } \\
(>85 \%) \text { (Van der } \\
\text { Molen, 2002) }\end{array}$ & & $\begin{array}{l}\text { 4-5 years: high level } \\
\text { of distractibility due to } \\
\text { irrelevant stimuli (Pasto \& } \\
\text { Burack, 1997) } \\
\text { 4-5 years: children } \\
\text { pay less attention to } \\
\text { oncoming traffic than } \\
\text { older children (Barton \& } \\
\text { Schwebel, 2007) } \\
\text { 4-5 years: attention is } \\
\text { more focused on things } \\
\text { that are not relevant } \\
\text { to traffic (Günther \& } \\
\text { Limbourg, 1977) }\end{array}$ & $\begin{array}{l}\text { from } 4 \text { years onwards: } \\
\text { children begin to } \\
\text { understand meta-repre- } \\
\text { sentations of the world } \\
\text { by developing theories } \\
\text { about what others think } \\
\text { or know (theory of mind). } \\
\text { These theories make it } \\
\text { easier for them to predict } \\
\text { the behaviour of others } \\
\text { (Premack \& Woodruf, } \\
\text { 1978) } \\
\text { 4-5 years: children can } \\
\text { deduce that someone } \\
\text { sees something they } \\
\text { cannot themselves see } \\
\text { (Flavell, 1992) } \\
\text { 4-6 years: children } \\
\text { understand that their } \\
\text { perception of the world } \\
\text { can differ from that of } \\
\text { others and also that there } \\
\text { can be incorrect beliefs } \\
\text { (Wimmer \& Perner, 1983) }\end{array}$ & $\begin{array}{l}4 \text { years: child asks "W" } \\
\text { questions (Michaelis \& } \\
\text { Niemann, 1999) } \\
4 \text { years: child distinguishes } \\
\text { and names identical objects of } \\
\text { different sizes, and is able to } \\
\text { differentiate these (for example } \\
\text { large and small apples) (Mi- } \\
\text { chaelis \& Niemann, 1999) } \\
4 \text { years: children are already } \\
\text { showing the beginnings of } \\
\text { successful inhibition in inhibition } \\
\text { tasks that are simple (e.g. } \\
\text { only inhibiting response) and } \\
\text { more complex (e.g. inhibiting } \\
\text { response and displaying alterna- } \\
\text { tive response) (Bjorklund, 2005). } \\
4-6 \text { years: more integrated } \\
\text { thinking (details move into the } \\
\text { background), purposeful think- } \\
\text { ing, events are conceivable, } \\
\text { symbolic thinking, extension } \\
\text { of knowledge through visual } \\
\text { acquisition (Böttcher, 2005) } \\
<5 \text { years: children are only } \\
\text { able to sort objects by one } \\
\text { criterion (Brooks, Hanauer, } \\
\text { Padowska, \& Rosman, 2003) }\end{array}$ & $\begin{array}{l}\text { 4-6 years: child can carry } \\
\text { out requested actions, ba- } \\
\text { sic understanding of the } \\
\text { rules of games, but the } \\
\text { use of these is variable } \\
\text { (Böttcher, 2005) } \\
4 \text { years: start of games } \\
\text { with rules (board games) } \\
\text { (Michaelis \& Niemann, } \\
\text { 1999) } \\
4 \text { years: child is ready } \\
\text { to share (Michaelis \& } \\
\text { Niemann, 1999) } \\
4 \text { years: child is generally } \\
\text { able to regulate his/her } \\
\text { emotions concerning } \\
\text { everyday events him/her- } \\
\text { self, certain tolerance to } \\
\text { sadness, disappointment, } \\
\text { joy, fear, anticipation, } \\
\text { stress (Michaelis \& } \\
\text { Niemann, 1999) } \\
4 \text { years: child knows } \\
\text { that he/she is a boy or girl } \\
\text { and behaves accordingly } \\
\text { (Michaelis \& Niemann, } \\
\text { 1999) }\end{array}$ & $\begin{array}{l}\text { 4-5 years: children have only } \\
\text { a very rudimentary concept of } \\
\text { danger, with situations being } \\
\text { recognised as dangerous } \\
\text { more readily than objects (Hill, } \\
\text { Lewis, \& Dunbar,2000) } \\
\text { 4-5 years: visual obstructions } \\
\text { are not perceived as dangers } \\
\text { by children of this age (Thomp- } \\
\text { son, 1997) } \\
\text { 4-5 years: children are } \\
\text { able to identify dangerous } \\
\text { situations and accidents, but } \\
\text { do not understand the cause } \\
\text { of the accident or how to } \\
\text { avoid danger (Hargreaves \& } \\
\text { Davies, 1996) }\end{array}$ & $\begin{array}{l}\text { 4-5 years: children cross the } \\
\text { road quickly and without prior } \\
\text { orientation (Limbourg, 1976) }\end{array}$ \\
\hline 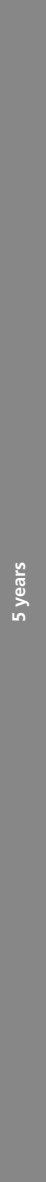 & $\begin{array}{l}5 \text { years: "slow } \\
\text { hearing" with regard } \\
\text { to registration, } \\
\text { identification, clas- } \\
\text { sification, unneliable } \\
\text { discrimination, inac- } \\
\text { curate localisation } \\
\text { (Finlayson, 1972) } \\
5 \text { years: directional } \\
\text { hearing is facilitated } \\
\text { by looking in the } \\
\text { relevant direction } \\
\text { (Warwitz, 2009) } \\
5-10 \text { years: } \\
\text { Depending on the } \\
\text { pitch (frequency), } \\
\text { children attain the } \\
\text { hearing threshold } \\
\text { of adults between } \\
\text { the ages of } 5 \text { and } \\
\text { 10. Prior to this, } \\
\text { noises are only heard } \\
\text { clearly from a higher } \\
\text { frequency (Werner \& } \\
\text { Marean, 1996) }\end{array}$ & $\begin{array}{l}5 \text { years: the speed } \\
\text { of loud cars is } \\
\text { overestimated, quiet } \\
\text { cars are perceived as } \\
\text { slower, which makes } \\
\text { control perception } \\
\text { necessary (Warwitz, } \\
\text { 2009) } \\
5 \text { years: children } \\
\text { are poor at iden- } \\
\text { tifying oncoming } \\
\text { vehicles or those } \\
\text { driving away from } \\
\text { them using acoustic } \\
\text { signals, meaning } \\
\text { that no directional } \\
\text { hearing is possible } \\
\text { (Pfeffer \& Barnecutt, } \\
\text { 1996) }\end{array}$ & $\begin{array}{l}\mathbf{5} \text { years: if you ask a } \\
\text { child to focus only on the } \\
\text { road traffic, he or she } \\
\text { will do so for } 15 \text { minutes } \\
\text { at most. Longer periods } \\
\text { of deliberate attention } \\
\text { place excessive demands } \\
\text { on the child (Walter et } \\
\text { al., 2013). } \\
\text { from approx. } 5 \text { years } \\
\text { onwards: children } \\
\text { develop systematic } \\
\text { strategies for attention } \\
\text { (Limbourg, 2008) } \\
\mathbf{5} \text { years: deterioration } \\
\text { of performance when } \\
\text { processing tasks } \\
\text { concerning the ability to } \\
\text { distinguish visually due to } \\
\text { minor acoustic distraction; } \\
\text { children made more } \\
\text { frequent mistakes and } \\
\text { strayed away from the } \\
\text { task (Higgins \& Turnure, } \\
\text { 1984) } \\
\mathbf{5 - 7} \text { years: attention } \\
\text { can be more consciously } \\
\text { controllled, but distract- } \\
\text { ibility as a result of } \\
\text { environmental stimuli is } \\
\text { still present (Limbourg, } \\
\text { 1997; 2008) }\end{array}$ & & $\begin{array}{l}5 \text { years: 5-year-olds need } \\
\text { approximately twice as long } \\
\text { as adults to make a decision } \\
\text { as a pedestrian (Schieber \& } \\
\text { Thompson, 1996) } \\
\text { from } 5 \text { years onwards: } \\
\text { children can sort objects } \\
\text { by } 2 \text { criteria, e.g. cards by } \\
\text { colour and shape (Brooks et } \\
\text { al., 2003) } \\
5-8 \text { years: children have } \\
\text { more difficulties choosing safe } \\
\text { routes to cross the road than } \\
\text { older children (Schwebel et } \\
\text { al., 2012) }\end{array}$ & $\begin{array}{l}5 \text { years: child can share } \\
\text { toys and sweets fairly } \\
\text { between him/herself and } \\
\text { others (Michaelis \& } \\
\text { Niemann, 1999) } \\
5 \text { years: Child invites } \\
\text { other children, is invited } \\
\text { (Michaelis \& Niemann, } \\
\text { 1999) } \\
5 \text { years: occasionally } \\
\text { still looks for close } \\
\text { physical contact: when } \\
\text { tired, exhausted, ill and } \\
\text { similar (Michaelis \& } \\
\text { Niemann, 1999) } \\
5 \text { years: Child can } \\
\text { report on embarrassing, } \\
\text { frustrating, unpleasant } \\
\text { incidents (Michaelis \& } \\
\text { Niemann, 1999) } \\
5 \text { years: Children play a } \\
\text { lot of role-playing games } \\
\text { (including with other chil- } \\
\text { dren), dress up as heroes, } \\
\text { role models (Michaelis \& } \\
\text { Niemann, 1999) }\end{array}$ & $\begin{array}{l}\mathbf{5} \text { years: Targeted individual } \\
\text { training (better than group } \\
\text { training) can improve the } \\
\text { safety strategies (selection } \\
\text { of safe route) in 5-year-old } \\
\text { children (Thompson, 1997) } \\
\mathbf{5} \text { years: dangerous situation } \\
\text { creates vague feeling of fear } \\
\text { that paralyses or leads to } \\
\text { panicky behavioural outbreaks } \\
\text { (Warwitz, 2009; Piaget, 1983) } \\
\mathbf{5} \text { years: children can gener- } \\
\text { ally recognise danger; their } \\
\text { weakness lies in transferring } \\
\text { and applying their knowledge } \\
\text { (Dunbar, Lewis, \& Hill, 1999) } \\
\mathbf{5 - 6} \text { years: beginning con- } \\
\text { sciousness of risk (Limbourg, } \\
\text { 2001) } \\
\mathbf{5 - 6} \text { years: Term "accident" } \\
\text { is falsely equated with injury } \\
\text { (near-misses are not classified } \\
\text { as danger) (Rollett, 1993) } \\
\mathbf{5 - 6} \text { years: Compared to } \\
\text { 7-8-year-olds, children take } \\
\text { more risks when crossing the } \\
\text { road and accept smaller gaps } \\
\text { between cars, which increases } \\
\text { the risk of a collision (Barton \& } \\
\text { Schwebel, 2007) } \\
\mathbf{5 - 7} \text { years: have low capacity } \\
\text { to detect dangers when cross- } \\
\text { ing the road (Ampofo-Boateng } \\
\text { \& Thompson, 1991) } \\
\mathbf{5 - 7} \text { years: the most direct } \\
\text { route is also seen as the safest } \\
\text { route when crossing the road, } \\
\text { lack of awareness for dangers } \\
\text { originating from obstacles } \\
\text { at the side of the road or } \\
\text { other visual restrictions (Am- } \\
\text { pofo-Boateng et al., 1993) }\end{array}$ & 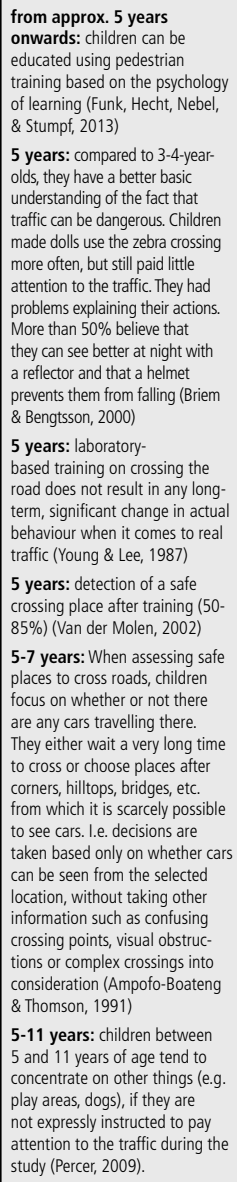 \\
\hline
\end{tabular}




\begin{tabular}{|c|c|c|c|c|c|c|c|c|c|c|}
\hline & \multicolumn{3}{|c|}{ MOTOR SKILLS } & \multicolumn{5}{|c|}{ VISUAL PERCEPTION } & \multicolumn{2}{|c|}{ ACOUSTIC PERCEPTION } \\
\hline बू & Gross motor skills & $\begin{array}{l}\text { Hand motor } \\
\text { control } \\
\text { / finger } \\
\text { dexterity }\end{array}$ & Effects in traffic & $\begin{array}{l}\text { Perception } \\
\text { of colour } \\
\text { / light and } \\
\text { dark }\end{array}$ & $\begin{array}{l}\text { Visual acuity } \\
\text { and accom- } \\
\text { modation }\end{array}$ & Peripheral vision & $\begin{array}{l}\text { Depth percep- } \\
\text { tion and spatial } \\
\text { perception }\end{array}$ & Effects in traffic & $\begin{array}{l}\text { General hearing } \\
\text { ability, direc- } \\
\text { tional hearing } \\
\text { and noise } \\
\text { differentiation }\end{array}$ & Effects in traffic \\
\hline & $\begin{array}{l}6 \text { years: stopping as a } \\
\text { pedestrian (>85\%) (Van der } \\
\text { Molen, 2002) } \\
6 \text { years: at least } 5 \text { sec. } \\
\text { standing on one leg (Michaelis \& } \\
\text { Niemann, 1999) } \\
6 \text { years: hopping on one leg } \\
\text { (Michaelis \& Niemann, 1999) } \\
6 \text { years: motor development } \\
\text { shows significant increase in } \\
\text { learning capacity (Limbourg, } \\
2008 \text { ) } \\
6 \text { years: catching a ball (Mi- } \\
\text { chaelis \& Niemann, 1999) } \\
6 \text { years: riding a bicycle } \\
\text { (Michaelis \& Niemann, 1999) } \\
6 \text { years: overestimation } \\
\text { of physical abilities when } \\
\text { performing physical exercises } \\
\text { (Plumert, 1995) }\end{array}$ & & $\begin{array}{l}6 \text { years: once } \\
\text { they have started } \\
\text { movement patterns, } \\
\text { children are frequently } \\
\text { unable to interrupt or } \\
\text { control them promptly. } \\
\text { They would not come } \\
\text { to an abrupt halt even } \\
\text { if it were necessary } \\
\text { (Brück, 2009) } \\
6 \text { years: while } \\
8 \text {-year-olds already } \\
\text { make use of learning } \\
\text { effects in their self-as- } \\
\text { sessment regarding } \\
\text { their vertical reach } \\
\text { and their judgment } \\
\text { is therefore more } \\
\text { accurate, this is } \\
\text { not yet possible for } \\
\text { 6-year-olds; they still } \\
\text { tend to overestimate } \\
\text { (Plumert, 1995). }\end{array}$ & & $\begin{array}{l}\text { 5-6 years: } \\
\text { visual } \\
\text { acuity values } \\
\text { correspond to } \\
\text { those of adult } \\
\text { test subjects } \\
\text { (Lai, Wang, \& } \\
\text { Hsu, 2011) } \\
6 \text { years: visual } \\
\text { acuity and } \\
\text { sensitivity to } \\
\text { contrast are } \\
\text { comparable to } \\
\text { what is found } \\
\text { in adults (El- } \\
\text { lemberg, Lewis, } \\
\text { Liu, \& Maurer, } \\
\text { 1999). }\end{array}$ & $\begin{array}{l}\text { 6-7 years: periph- } \\
\text { eral vision is 70\% } \\
\text { developed, objects } \\
\text { approaching from } \\
\text { the side are outside } \\
\text { the field of vision } \\
\text { for a long time } \\
\text { (Walter, Achermann } \\
\text { Stürmer, Scaramuz- } \\
\text { za, Niemann, \& } \\
\text { Cavegn, 2013) } \\
\mathbf{6 - 8} \text { years: } \\
\text { children in this } \\
\text { age group need } \\
\text { longer to react to } \\
\text { optical stimuli in } \\
\text { their peripheral } \\
\text { field of vision than } \\
\text { 11-year-olds and } \\
\text { adults (David, } \\
\text { Foot, Chapman, \& } \\
\text { Sheehy, 1986). }\end{array}$ & \begin{tabular}{|l|}
6 years: ade- \\
quate estimation \\
of distances (50- \\
$85 \%$ ) (Van der \\
Molen, 2002) \\
6-7 years: \\
difficulties in inter- \\
preting the speed \\
and direction of \\
moving objects/ \\
vehicles (Joly, \\
Foggin \& Pless, \\
1991 ) \\
6-7 years: \\
adequate \\
understanding of \\
spatial relations \\
(50-85\%) (Van \\
der Molen, 2002)
\end{tabular} & $\begin{array}{l}6-7 \text { years: only } 32 \% \text { are able } \\
\text { to estimate speeds correctly } \\
\text { (Günther \& Limbourg, 1977) } \\
6-7 \text { years: when crossing the } \\
\text { road, children principally orient- } \\
\text { ed themselves on the edge of } \\
\text { the pavement, then ran across } \\
\text { the road without additional } \\
\text { orientation (Limbourg 1976) }\end{array}$ & $\begin{array}{l}6 \text { years: still } \\
\text { uncertainty with } \\
\text { noise localisation, } \\
\text { noises are only } \\
\text { correctly attributed } \\
\text { from in front or } \\
\text { behind (Dordel \& } \\
\text { Kunz, 2005) }\end{array}$ & $\begin{array}{l}\text { from } 6 \text { years } \\
\text { onwards: hearing } \\
\text { ability fully devel- } \\
\text { oped, but not yet } \\
\text { regularly drawn on } \\
\text { in traffic (Finlayson, } \\
\text { 1972) }\end{array}$ \\
\hline & $\begin{array}{l}\text { 6-7 years: stopping actions } \\
\text { after they have been started } \\
\text { is possible, but is linked to } \\
\text { guidance (Limbourg, 1976) } \\
6-7 \text { years: } 63 \% \text { of the } 6 \text { to } \\
\text { 7-year-old children needed } \\
\text { less than } 1 \text { second to interrupt } \\
\text { their action (cranking toy cars } \\
\text { attached by string over a long } \\
\text { plank using a hand crank) in } \\
\text { responsse to a signal (Limbourg, } \\
1995 \text { ) } \\
\text { 6-7 years: posture in balance } \\
\text { tasks is 3-6 times more unstable } \\
\text { compared to adults, due to } \\
\text { children's higher centre of mass. } \\
\text { Children have only 15\% of the } \\
\text { capability of } 25 \text {-year-old adults } \\
\text { (Basner \& de Marées, 1993) } \\
7-8 \text { years: developmental } \\
\text { leap in psychomotor skills with } \\
\text { a significant improvement in } \\
\text { performance (Arnberg, Ohlsson, } \\
\text { Westerberg, \& Öström, 1978) }\end{array}$ & & $\begin{array}{l}\text { 7-8 years: better } \\
\text { performance in terms } \\
\text { of balance regulation } \\
\text { following increased } \\
\text { cycle training or } \\
\text { increased bicycle use } \\
\text { (Basner \& De Marees, } \\
\text { 1993) } \\
\text { Primary school } \\
\text { age: children with } \\
\text { motor impairments } \\
\text { are not able to } \\
\text { master whole basic } \\
\text { requirements when } \\
\text { it comes to cycling. } \\
\text { This affects safely } \\
\text { staying in lane while } \\
\text { looking sideways or } \\
\text { backwards, bove all } \\
\text { when combined with } \\
\text { intended changes } \\
\text { of direction and the } \\
\text { indication of these } \\
\text { (including to the } \\
\text { right) (Günther \& } \\
\text { Degener, 2009) }\end{array}$ & & & $\begin{array}{l}\text { from } 7 \text { years on- } \\
\text { wards: peripheral } \\
\text { perception required } \\
\text { for stimuli encoun- } \\
\text { tered in traffic is } \\
\text { fully developed } \\
\text { (Schwebel, Davis, \& } \\
\text { O'Neal, 2012) }\end{array}$ & \begin{tabular}{|l}
$7-8$ years: \\
improvement \\
regarding visual \\
search strategies \\
in traffic (White- \\
bread \& Neilson, \\
2000) \\
$7-8$ years: \\
improvement in \\
gaze behaviour, \\
more frequent di- \\
rectional changes \\
in visual attention \\
and reduced gaze \\
duration in one \\
direction lead to \\
an improvement \\
in collecting \\
information from \\
various directions \\
(Whitebread \& \\
Neilson, 2000).
\end{tabular} & $\begin{array}{l}\text { from } 7 \text { years onwards: } \\
\text { peripheral perception required } \\
\text { for stimuli encountered in traffic } \\
\text { is fully developed (Schwebel et } \\
\text { al., 2012) } \\
\text { < 7-8 years: children younger } \\
\text { than 7-8 years tend to be less } \\
\text { efficient in their visual search } \\
\text { and to ignore disturbing infor- } \\
\text { mation. They also perform more } \\
\text { poorly in pedestrian crossing } \\
\text { tasks (Barton, 2006) } \\
7-8 \text { years: the move to an } \\
\text { effective application of visual } \\
\text { search abilities appears to take } \\
\text { place at the age of } 7-8 \text { years } \\
\text { (Whitebread \& Neilson, 2000). } \\
7-8 \text { years: when cycling, } 7 \text { to } \\
\text { 8-year-olds focus more on central } \\
\text { vision, in order to maintain their } \\
\text { balance on the bicycle, while less } \\
\text { attention is paid to information } \\
\text { relevant to trafficin the peripher- } \\
\text { al area (Ellis, 2014) } \\
\text { 7-10 years: unfavourable } \\
\text { visual search strategies (Tapiro, } \\
\text { Oron-Gilad, \& Parmet, 2016): } \\
\text { surroundings are scanned in } \\
\text { a hectit manner using more fre- } \\
\text { quent and shorter fixations }\end{array}$ & & \\
\hline & $\begin{array}{l}8 \text { years: child can master } \\
\text { difficult manoeuvres on a bicycle } \\
\text { (riding a slalom, stabilising the } \\
\text { bicycle while riding slowly, etc.) } \\
\text { (Pfafferott, 1994) } \\
8 \text { years: children are able to } \\
\text { estimate physical abilities more } \\
\text { accurately when performing } \\
\text { physical exercises (Plumert, } \\
\text { 1995) } \\
8 \text { years: cycling without wob- } \\
\text { bling when stopping (>85\%) } \\
\text { (Michaelis \& Niemann, 1999) } \\
8-9 \text { years: } 91 \% \text { of the } 8 \text { to } \\
9 \text {-year-old children needed } \\
\text { less than } 1 \text { second to interrupt } \\
\text { their action (cranking toy cars } \\
\text { attached by string over a long } \\
\text { plank using a hand crank) in } \\
\text { response to a signal (Limbourg, } \\
1995) \\
8-10 \text { years: on average, } \\
\text { children required } 0.8 \text { seconds } \\
\text { of reaction time, } 10 \text {-year-olds } \\
\text { required } 0.6 \text { second and adults } \\
\text { only } 0.4 \text { seconds (Hoffmann, } \\
\text { Martin, \& Schilling, 2003) }\end{array}$ & & $\begin{array}{l}\text { 8-9 years: children } \\
\text { cross the road at } \\
\text { normal walking } \\
\text { speed and orientate } \\
\text { themselves by the } \\
\text { various areas of the } \\
\text { road (pavement, } \\
\text { edge of pavement, } \\
\text { line of sight) } \\
\text { (Limbourg, 1976) }\end{array}$ & $\begin{array}{l}>8 \text { years: } \\
\text { contrast } \\
\text { sensitivity } \\
\text { develops fully } \\
\text { between } 8 \\
\text { and } 19 \text { years } \\
\text { of age (Leat, } \\
\text { Yadav, \& } \\
\text { Irving, 2009) }\end{array}$ & & $\begin{array}{l}8 \text { years: for 8-year- } \\
\text { olds, central vision } \\
\text { is predominantly } \\
\text { important in order } \\
\text { to maintain balance } \\
\text { in a stable manner. } \\
\text { In comparison, for } \\
\text { 6-year-olds and/ } \\
\text { or } 10 \text {-year-olds, } \\
\text { central and periph- } \\
\text { eral vision is equally } \\
\text { important for stable } \\
\text { postural control } \\
\text { (Nougier, Bard, } \\
\text { Fleury, \& Teasdale, } \\
\text { 1998). } \\
\text { 8-9 years: pe- } \\
\text { ripheral perception } \\
\text { (>85\%) (Van der } \\
\text { Molen, 2002) }\end{array}$ & \begin{tabular}{|l} 
8-9 years: \\
understanding of \\
spatial relation- \\
ships (>85\%) \\
(Van der Molen, \\
2002) \\
8-9 years: ade- \\
quate estimation \\
of distances \\
$(>85 \%)$ (Van der \\
Molen, 2002)
\end{tabular} & $\begin{array}{l}\text { up to } 8 \text { years: children had } \\
\text { problems looking in a different } \\
\text { direction to the direction of } \\
\text { travel. If they did try to do so, } \\
\text { they had great difficulties in } \\
\text { keeping their balance (Küting, } \\
\text { Boigs, \& Winkler, 1979) } \\
8-9 \text { years: only } 43 \% \text { of the } \\
\text { children were able to estimate } \\
\text { speeds correctly (Günther \& } \\
\text { Limbourg, 1977) } \\
\text { < } 9 \text { years: when deciding } \\
\text { whether to cross the road, } \\
\text { children principally take visual } \\
\text { stimuli into consideration, i.e. } \\
\text { whether or not a car is visible } \\
\text { (Ampofo-Boateng \& Thompson, } \\
\text { 1989) }\end{array}$ & $\begin{array}{l}\text { from } 8 \text { years on- } \\
\text { wards: adequate } \\
\text { interpretation of } \\
\text { sound impressions } \\
\text { (Wildner et al., } \\
\text { 2009) } \\
\text { from 8-9 years } \\
\text { onwards: } \\
\text { directional hearing } \\
\text { functions (Pfeffer \& } \\
\text { Barnecutt, 1996) } \\
\text { 8-9 years: due } \\
\text { to the greater } \\
\text { negative impact of } \\
\text { reflecting sounds, } \\
\text { directional hearing } \\
\text { in a real-world } \\
\text { road setting } \\
\text { appears only to } \\
\text { be fully developed } \\
\text { from the age of 8-9 } \\
\text { years (Barton, Lew, } \\
\text { Kovesdi, Cottrell, \& } \\
\text { Ulrich, 2013). }\end{array}$ & $\begin{array}{l}\mathbf{8} \text { years: hearing is } \\
\text { regularly called on } \\
\text { in traffic (Finlayson, } \\
\text { 1972) } \\
\mathbf{8} \text { years: less } \\
\text { than } 50 \% \text { of the } \\
\text { vehicle sounds } \\
\text { (driving away } \\
\text { vs. approaching) } \\
\text { could be correctly } \\
\text { recognised (Pfeffer } \\
\& \text { Barnecutt, } \\
\text { 1996). }\end{array}$ \\
\hline & $\begin{array}{l}\text { from } 9 \text { years onwards: } \\
\text { significant improvement in } \\
\text { cycling one-handed (Basner and } \\
\text { De Marées, 1993) } \\
9 \text { 9-10 years: motor skills for } \\
\text { cycling, such as maintaining } \\
\text { balance, braking, steering, } \\
\text { staying in lane or keeping to a } \\
\text { line in corners, are developed } \\
\text { (Limbourg, 1997) }\end{array}$ & & & & & & $\begin{array}{l}9 \text { years: depth- } \\
\text { of-field perception } \\
\text { is fully developed } \\
\text { (Limbourg, 2008) } \\
\text { 9-10 years: ade- } \\
\text { quate estimation } \\
\text { of speeds (>85\%) } \\
\text { (Michaelis \& } \\
\text { Niemann, 1999) }\end{array}$ & & \begin{tabular}{|l|} 
from 9 years \\
onwards: signal \\
direction is rec- \\
ognised (Wildner et \\
al., 2009)
\end{tabular} & \\
\hline
\end{tabular}


Table 1: TRAFFIC SKILLS AND THEIR FOUNDATIONS

\begin{tabular}{|c|c|c|c|c|c|c|}
\hline & \multicolumn{6}{|c|}{ COGNITIVE DEVELOPMENT } \\
\hline षे & $\begin{array}{l}\text { Attentiveness (selective, } \\
\text { duration, divided, } \\
\text { distractibility) }\end{array}$ & $\begin{array}{l}\text { Ability to adopt other } \\
\text { perspectives }\end{array}$ & Thinking & $\begin{array}{l}\text { Social and emotional } \\
\text { competence }\end{array}$ & Hazard perception & Effects in traffic \\
\hline & $\begin{array}{l}6 \text { years: children in traffic } \\
\text { direct their attention to rele- } \\
\text { vant stimuli just as frequently } \\
\text { as irrelevant stimuli (Tolmie } \\
\text { et al., 2005) } \\
6-8 \text { years: children have a } \\
\text { system of paying attention } \\
\text { that functions comparably } \\
\text { well to that of an adult (Ristic, } \\
2009 \text { ). } \\
6-10 \text { years: performance } \\
\text { improves significantly in tasks } \\
\text { where unimportant stimuli } \\
\text { are incorporated into the task } \\
\text { and a test is carried out to } \\
\text { see how focused the child } \\
\text { remains on the important } \\
\text { aspects (Gómez-Pérez \& } \\
\text { Ostrosky-Solis, 2006) }\end{array}$ & $\begin{array}{l}6 \text { years: children already } \\
\text { have a kind of "theory of } \\
\text { mind" (Cox, 1991) } \\
\text { 6-8 years (Limbourg, 2008) } \\
\text { or 6-7 years (Piaget, 1983): } \\
\text { subjective adoption of } \\
\text { perspective: The child is able } \\
\text { to understand that another } \\
\text { person also has his/her own } \\
\text { perspective, based on his/ } \\
\text { her own thinking. This may } \\
\text { be similar to one's own per- } \\
\text { spectives or not. The child is } \\
\text { only ever able to concentrate } \\
\text { on one perspective. However, } \\
\text { he or she understands that } \\
\text { other people's actions, just } \\
\text { like his or her own, are partly } \\
\text { determined by thoughts and } \\
\text { feelings, and knows the dif- } \\
\text { ference between intentional } \\
\text { and unintentional actions. }\end{array}$ & $\begin{array}{l}\text { 6-8 years: simple } \\
\text { strategies for drawing } \\
\text { conclusions, acquisition of } \\
\text { systematic, ready-to-use } \\
\text { knowledge begins, if-then } \\
\text { thinking: naming of causes } \\
\text { based on practical experi- } \\
\text { ence (Böttcher, 2005) } \\
6-12 \text { years: concrete-op- } \\
\text { erational stage (Piaget, } \\
\text { 1983) }\end{array}$ & \begin{tabular}{|l|} 
6-8 years: learning social \\
norms and rules, switch \\
between non-binding use \\
and very close monitoring \\
in shared play (Böttcher, \\
2005) \\
from 6 years onwards: \\
children are more \\
motivated to complete \\
tasks on their own, explore \\
their own limits and those \\
of the group (Kellmann \& \\
Arterberry, 2006) \\
from 6 years onwards: \\
children become \\
increasingly independent \\
of caregivers (Kellmann \& \\
Arterberry, 2006)
\end{tabular} & $\begin{array}{l}\text { < } \boldsymbol{\sigma} \text { years: the speed of an approaching } \\
\text { car is perceived as a greater potential risk } \\
\text { factor compared to its distance (Rosenbloom, } \\
\text { Nemrodov, Ben-Eliyahu, \& Eldror, 2008) } \\
6-7 \text { years: children can recognise accidents, } \\
\text { dangerous situations and preventative } \\
\text { measures more comprehensively than younger } \\
\text { children. They begin to recognise their role as } \\
\text { possible cause of a situation (Hargreaves \& } \\
\text { Davies, 1996) } \\
6-7 \text { years: detection of a safe crossing } \\
\text { place without training (<50\%) (Michaelis \& } \\
\text { Niemann, 1999) } \\
6-8 \text { years: accident risk increases continually } \\
\text { (Richter, Gruner, Rollow, \& Schneiders, 2006) } \\
6-9 \text { years: inexperience and lack of } \\
\text { knowledge are the main causes of accidents } \\
\text { (Schneider, 2001) } \\
6-17 \text { years: fearful children have just as many } \\
\text { accidents as very lively, extroverted children; } \\
\text { boys are involved in accidents more frequently } \\
\text { than girls (Richter, Schlag, \& Schupp, 2006) }\end{array}$ & $\begin{array}{l}6 \text { years: children are more easily distracted by irrelevant } \\
\text { stimuli than older children (Barton \& Morongiello, 2011) } \\
6 \text { years: children know that a helmet cannot prevent a fall, } \\
\text { can distinguish between "falling" and "being injured", and } \\
\text { understand that reflectors contribute to their own visibility. } \\
\text { However, there is mostly still no understanding of reciprocal } \\
\text { communication between children and other traffic partici- } \\
\text { pants at a zebra crossing (Briem \& Bengtsson, 2000) } \\
6-7 \text { years: while safe road behaviour at lights and zebra } \\
\text { crossings is learned somewhat earlier, crossing the road at } \\
\text { unregulated points and those with restricted visibility is still } \\
\text { very difficult for } 6 \text { to } 7 \text {-year-old children (Limbourg, 2010) } \\
6 \text {-14 years: children have the highest risk of having an } \\
\text { accident as cyclists in traffic, a medium risk as pedestrians } \\
\text { and a low risk as car passengers and train/bus users (Richter } \\
\text { et al., 2006) }\end{array}$ \\
\hline त्र & $\begin{array}{l}\text { 7-8 years: easy stimulation/ } \\
\text { distraction during processing } \\
\text { of a task led to fewer mis- } \\
\text { takes; there were indications } \\
\text { that the ability to gain an } \\
\text { overview of the situation } \\
\text { decreased as noise levels } \\
\text { increased (Higgins \& Turnure, } \\
\text { 1984) }\end{array}$ & $\begin{array}{l}7 \text { years: there is a con- } \\
\text { sciousness that people make } \\
\text { assumptions about other } \\
\text { people's assumptions, and } \\
\text { that these can be incorrect. } \\
\text { If a child is aware of the } \\
\text { existence of incorrect second } \\
\text { order beliefs, he or she can } \\
\text { draw conclusions as to the } \\
\text { reasons for these (Astington, } \\
\text { Pelletier, \& Homer, 2002) }\end{array}$ & $\begin{array}{l}7 \text { years: distinction } \\
\text { between left and right } \\
\text { possible (Limbourg \& } \\
\text { Senckel, 1976) }\end{array}$ & & $\begin{array}{l}\text { 7-8 years: hazard perception is based on } \\
\text { the existence of certain objects (e.g. a large } \\
\text { car), while the object's surroundings are } \\
\text { ignored (Underwood, Dillon, Farnsworth, \& } \\
\text { Twiner, 2007) } \\
7-8 \text { years: while hazard perception is still } \\
\text { rather idiosyncratic and self-centred at the } \\
\text { age of 7-8, in older children (11-11 years) } \\
\text { this changes to a more global perspective on } \\
\text { traffic events (Underwood et al., 2007) } \\
7-9 \text { years: children react less often to po- } \\
\text { tential dangers (Meir, Oron-Gilad, \& Parmet, } \\
\text { 2015a, 2015b) }\end{array}$ & 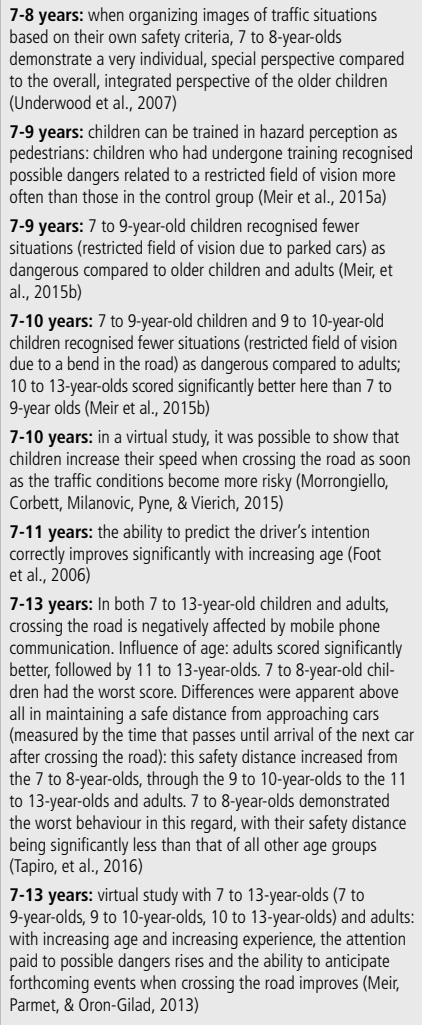 \\
\hline & $\begin{array}{l}8 \text { years: in comparison with } \\
11 \text {-year-olds, 8-year-olds have } \\
\text { more difficulties in coordinat- } \\
\text { ing and controlling the focus } \\
\text { of their attention (Irwin-Chase } \\
\& \text { Burns, 2000) } \\
\text { from } 8 \text { years onwards: } \\
\text { concentration is possible for a } \\
\text { relatively long period of time } \\
\text { (Limbourg, 1997) } \\
>8 \text { years: children are less } \\
\text { skilled at directing their } \\
\text { attention to relevant infor- } \\
\text { mation than older children } \\
\text { (Miller \& Weiss, 1981; Welsh, } \\
\text { Pennington, \& Groisser, 1991; } \\
\text { Trick \& Enns, 1998) } \\
\text { 8-9 years: selective attention } \\
\text { is developed (Tabibi \& Pfeffer, } \\
\text { 2003) }\end{array}$ & $\begin{array}{l}\text { 8-10 years: subjective } \\
\text { adoption of perspective: child } \\
\text { can place him/herself in the } \\
\text { position of someone else and } \\
\text { knows that the other person } \\
\text { can do the same (Limbourg, } \\
\text { 2008). The child knows that, } \\
\text { in principle, everyone can } \\
\text { reflect on the behaviour of } \\
\text { other people. Children of } \\
\text { this age are able to form } \\
\text { chains of perspectives. For } \\
\text { example: "I know that the } \\
\text { other person knows that } \\
\text { I know..." }\end{array}$ & $\begin{array}{l}\text { 8-9 years: it is not } \\
\text { the shortest route that } \\
\text { is selected, but rather } \\
\text { the safest (Günther \& } \\
\text { Limbourg, 1977) } \\
\text { 8-10/11 years: } \\
\text { development of theoretical } \\
\text { and simple deductive } \\
\text { thinking, thought processes } \\
\text { are uncoupled from } \\
\text { concrete objects, causal } \\
\text { thinking: cause and effect } \\
\text { relationships, ascertaining } \\
\text { of complex structures and } \\
\text { understanding of propor- } \\
\text { tions (Böttcher, 2005) }\end{array}$ & \begin{tabular}{|l|} 
8-10/11 years: binding \\
norms and rules determine \\
social behaviour; change of \\
rules when those involved \\
agree (Böttcher, 2005)
\end{tabular} & $\begin{array}{l}\text { approx. } 8 \text { years: forward-looking aware- } \\
\text { ness of risk develops (Limbourg, 2001) } \\
\text { approx. } 8 \text { years: children are increasingly } \\
\text { competent at putting a reflective, less } \\
\text { impulsive style of behaviour into practice, and } \\
\text { this is reflected in safety-conscious actions } \\
\text { (Rollett, 1993) } \\
\text { 8-10 years: boys demonstrate more } \\
\text { risky behaviour than girls of the same age } \\
\text { (Walesa, 1975) } \\
\text { 8-11 years: children can recognise dangers } \\
\text { in relation to their perspective and that of the } \\
\text { adults. They can distinguish between coping } \\
\text { and avoidance strategies when dealing with } \\
\text { dangers (Hargreaves \& Davies, 1996) }\end{array}$ & $\begin{array}{l}\text { 8 years: children can control their attention to some extent. } \\
\text { They can distinguish between relevant, irrelevant and neutral } \\
\text { stimuli. These stimuli may facilitate paying attention in a } \\
\text { selective manner or hinder it (Pearson \& Lane, 1990). } \\
8-9 \text { years: up to the age of approximately 8, children's } \\
\text { behaviour as pedestrians is risky and not very reliable. Even } \\
\text { older children ( } 8 \text { to } 9 \text { years) can sometimes still be distracted } \\
\text { and then cease to exhibit safe road behaviour. Both as } \\
\text { pedestrians and cyclists, boys are more at risk than girls, due } \\
\text { to their leisure activities and their greater willingness to take } \\
\text { risks (Limbourg, 2010). } \\
\text { 8-9 years: } \text { : etection of a safe crossing place without training } \\
\text { (50-85\%) (Michaelis \& Niemann, 1999) }\end{array}$ \\
\hline & & & & & $\begin{array}{l}\text { < } 9 \text { years: children show a low awareness } \\
\text { of possible dangers when crossing the road } \\
\text { (Oron-Gilad, Meir, Tapiro, \& Borowsky, 2011) } \\
9 \text { years: speed and distance are evaluated } \\
\text { separately as potential risk factors, but not in } \\
\text { combination, risks are evaluated in the same } \\
\text { way for children as for adults (Rosenbloom } \\
\text { et al., 2008) } \\
\text { 9-10 years: preventative risk awareness is } \\
\text { present (Limbourg, 2001) } \\
\mathbf{9 - 1 0 ~ y e a r s : ~ p e r c e p t i o n ~ a n d ~ a n t i c i p a t i o n ~ o f ~} \\
\text { risks }(>85 \%) \text { (Michaelis \& Niemann, 1999) }\end{array}$ & $\begin{array}{l}\text { 9-10 years: older children, who are more cautious, are } \\
\text { also more resistant to distracting information than younger } \\
\text { children (Dunbar, Hill \& Lewis, 2001; Tabibi \& Pfeffer, 2003). } \\
\text { 9-13 years: } 9 \text { to 13-year-olds cross roads (in a virtual study) } \\
\text { more hesitantly than experienced adults (Meir, et al., 2013) }\end{array}$ \\
\hline
\end{tabular}


Table 1: TRAFFIC SKILLS AND THEIR FOUNDATIONS

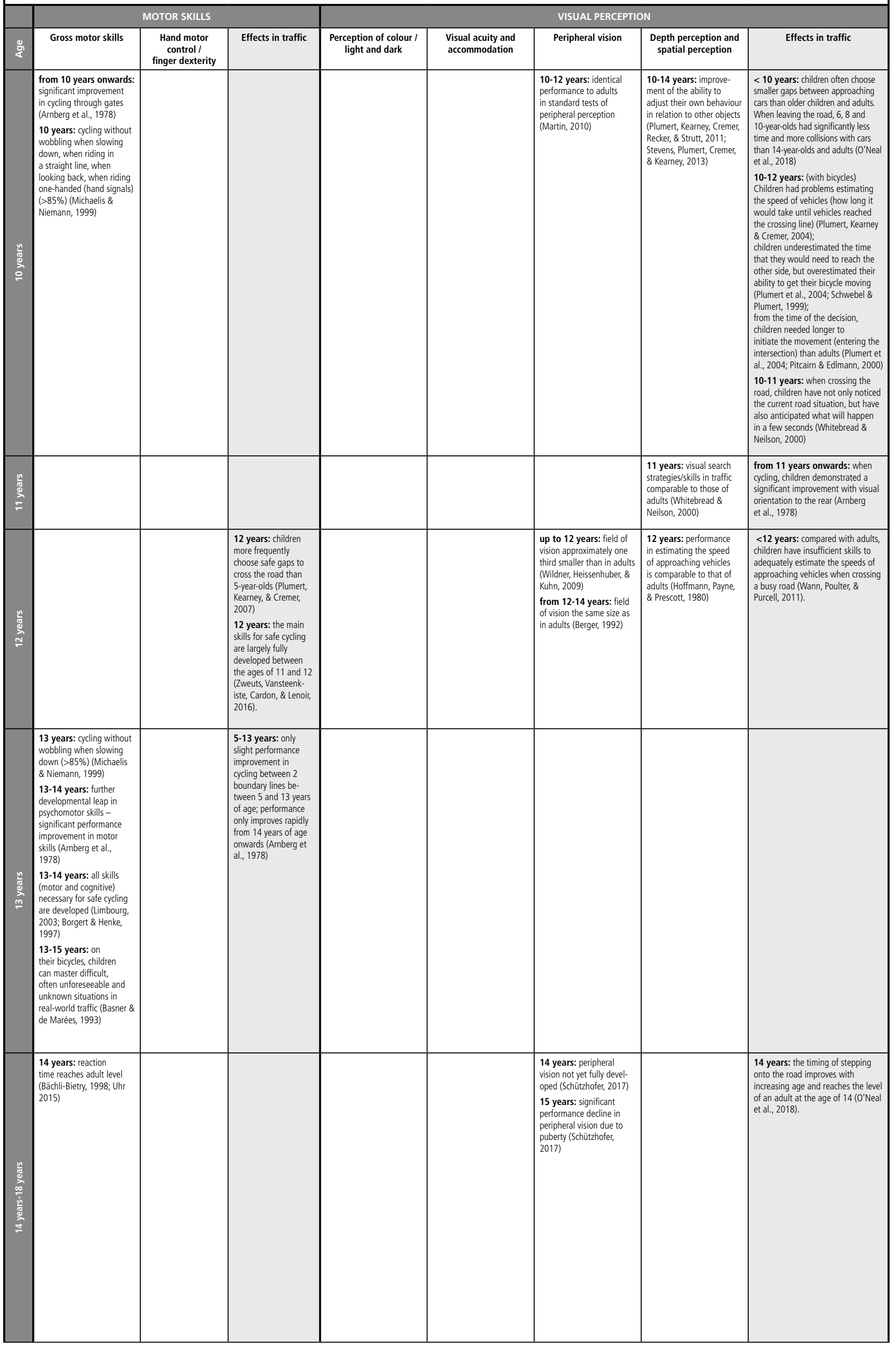


Table 1: TRAFFIC SKILLS AND THEIR FOUNDATIONS

\begin{tabular}{|c|c|c|c|c|c|c|c|c|}
\hline \multirow[b]{2}{*}{ ๕ัँ } & \multicolumn{2}{|c|}{ ACOUSTIC PERCEPTION } & \multicolumn{6}{|c|}{ COGNITIVE DEVELOPMENT } \\
\hline & $\begin{array}{l}\text { General hearing } \\
\text { ability, directional } \\
\text { hearing and noise } \\
\text { differentiation }\end{array}$ & $\begin{array}{l}\text { Effects in } \\
\text { traffic }\end{array}$ & $\begin{array}{l}\text { Attentiveness (selective, } \\
\text { duration, divided, } \\
\text { distractibility) }\end{array}$ & $\begin{array}{l}\text { Ability to adopt other } \\
\text { perspectives }\end{array}$ & Thinking & $\begin{array}{c}\text { Social and emotional } \\
\text { competence }\end{array}$ & Hazard perception & Effects in traffic \\
\hline مٍ & 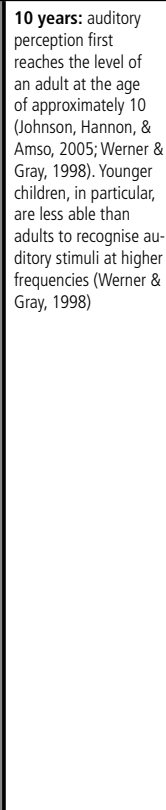 & & & $\begin{array}{l}\text { 10-12 years: reciprocal } \\
\text { adoptition of perspective: } \\
\text { children can now step away } \\
\text { from a two-person interac- } \\
\text { tion and place themelves } \\
\text { in the position of athir } \\
\text { person (Limbourg, 2008) }\end{array}$ & & $\begin{array}{l}\text { 10-11 years: understand- } \\
\text { ing of ambivalent emotions } \\
\text { (Schneider \& Lindenberger, } \\
\text { 2012) }\end{array}$ & 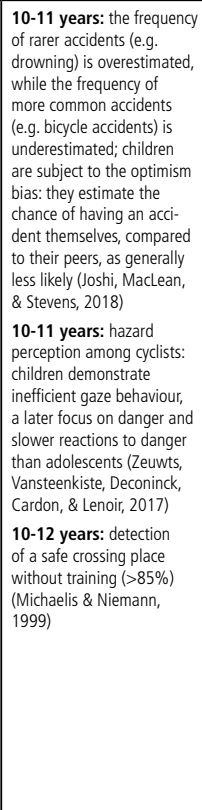 & 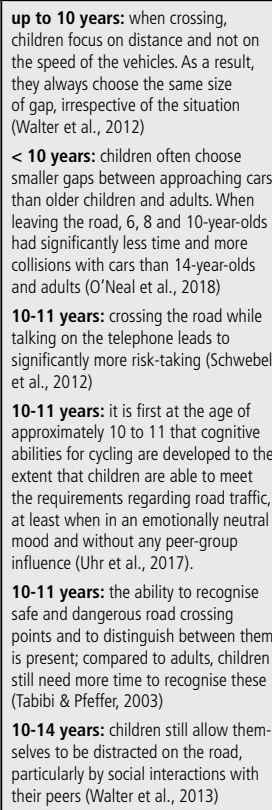 \\
\hline 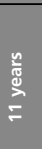 & $\begin{array}{l}11 \text { years: were able } \\
\text { to correctly identify } \\
60 \% \text { of vehicle noises } \\
\text { (driving away ys } \\
\text { approaching) (Pfeffer } \\
\text { \& Barnecutt, 1996) }\end{array}$ & & & & & & $\begin{array}{l}11 \text { years: children can es- } \\
\text { timate risks when crossing } \\
\text { the road (Ampofo-Boateng } \\
\text { \& Thomson, 1991) }\end{array}$ & $\begin{array}{l}11 \text { years: children are able to make } \\
\text { adequately safe estimates to cross } \\
\text { the road safely (Ampofo-Boateng \& } \\
\text { Thomson, 1991). }\end{array}$ \\
\hline 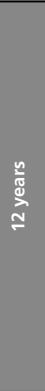 & & & 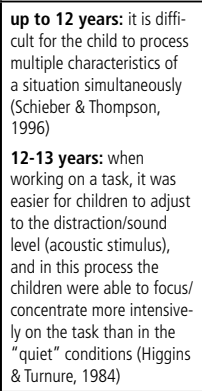 & & $\begin{array}{l}\text { 12-14 years: shifting/task } \\
\text { switching as components } \\
\text { of executive functions is } \\
\text { successful even in complex } \\
\text { situations where it is nec- } \\
\text { essarnt to switch between } \\
\text { mental states, actions or } \\
\text { tasks (Best, Miller, \& Jones, } \\
\text { 2009; Best \& Miller, 2010) }\end{array}$ & & $\begin{array}{l}\text { 11-12 years: perception } \\
\text { of complex traffic situations } \\
\text { takes place both heffectively } \\
\text { and in full (Pettit \& Janks, } \\
\text { 1996) }\end{array}$ & $\begin{array}{l}\text { Executive functions: adolescents } \\
\text { are able to estimate risks in a rational } \\
\text { manner with similar accurary to } \\
\text { adults, yet they still behave in a more } \\
\text { risky fashion as their behaviour is } \\
\text { more strongly controlled by rewards } \\
\text { (recognition of their peers) (Konrad, } \\
\text { Firk, \& Uhlhasa, 2013) }\end{array}$ \\
\hline 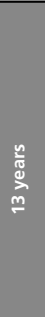 & & & $\begin{array}{l}\text { 13-14 years: attention } \\
\text { and concentration fully } \\
\text { developed (Dordel \& Kunz, } \\
\text { 2005) } \\
\text { 13-14 years: all skills } \\
\text { (motor and congitive) nec- } \\
\text { essary for safe cycling are } \\
\text { developed (Limbourg, 2003; } \\
\text { Borgert \& Henke, , } 999 \text { ) } \\
\text { 13-14 years: development } \\
\text { of attention is not complete } \\
\text { until around 13-14 years of } \\
\text { age (Limbourg, 1997) }\end{array}$ & & & $\begin{array}{l}\text { 13-16 years: taking risks } \\
\text { and making risky decisions } \\
\text { decreases with increasing } \\
\text { age (3 age groups: 13-16 } \\
\text { years, } 18-22 \text { years, adults } \\
\text { from } 24 \text { yearss). For younger } \\
\text { age groups (13-16 years } \\
\text { and } 18-22 \text { years), the pres- } \\
\text { ence of a peer group leads } \\
\text { to riskier behaviour and } \\
\text { riskier decisions than is the } \\
\text { case with adults (Gardner \& } \\
\text { Steinberg, 2005). }\end{array}$ & & $\begin{array}{l}\text { 13-14 years: the willingness to } \\
\text { comply with rules and to behave in a } \\
\text { risk-yware manner falls significantly, } \\
\text { while the peer group's influence on } \\
\text { risk behaviour in traffic increases } \\
\text { (Schützhofer, 2017) }\end{array}$ \\
\hline 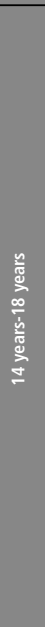 & & & 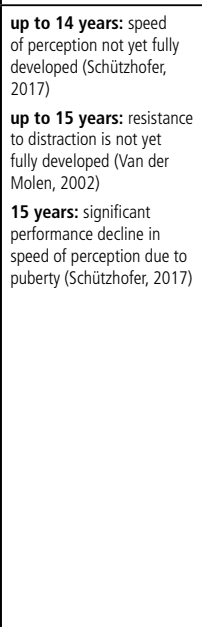 & & 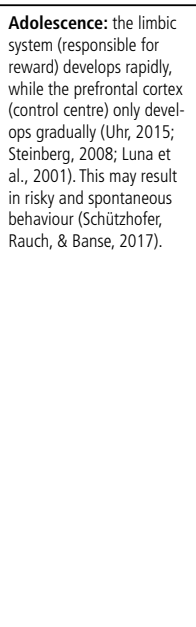 & 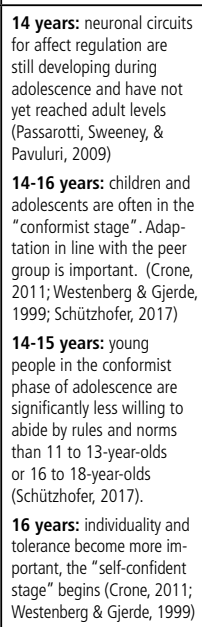 & \begin{tabular}{|l|} 
14-17 years: accidents \\
are increasingly caused by \\
conscious rule violations \\
(Schneider, 2001)
\end{tabular} & 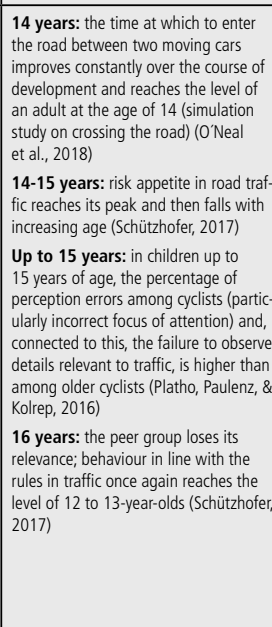 \\
\hline
\end{tabular}




\section{References to Table 1}

Ampofo-Boateng, K., \& Thompson, J. A. (1989). Child pedestrian accidents: a case for preventive medicine. Health Education Research: Theory and Practice, 5, 265-274.

Ampofo-Boateng, K., \& Thomson, J. A. (1991). Children's perception of safety and danger on the road. British Journal of Psychology, 82(4), 487-505.

Ampofo-Boateng, K., Thomson, J. A., Grieve, R., Pitcainr, T., Lee, D. N., \& Demetre, J. D. (1993). A developmental and training study of children's ability to find safe routes to cross the road. British Journal of Developmental Psychology, 11(1), 31-45.

Arnberg, P., Ohlsson, E., Westerberg, A., \& Öström, C. (1978). The ability of preschool and school children to manoeuvre their bicycles. VTI-Rapport Nr. 149A, Statens väg. Och. Trafikinstitut. Linköping. Astington, J. W., Pelletier, J., \& Homer, B. (2002). Theory of mind and epistemological development: The relation between children's second-order false-belief understanding and their ability to reason about evidence. New Ideas in Psychology, 20(2), 131-144.

Balster, K. (1998). Kinder mit mangelnden Bewegungserfahrungen. Teil 29. Praktische Beobachtungshilfen zur Einschätzung und Förderung kindlichen Bewegungsverhaltens. Duisburg: SpuRt. Barton, B. K. (2006). Integrating selective attention into developmental pedestrian safety research. Canadian Psychology, 47(3), 203-210.

Barton, B. K., \& Schwebel, D. C. (2007). The roles of age, gender, inhibitory control, and parenta supervision in children's pedestrian safety. Journal of Pediatric Psychology, 32(5), 517-526.

Barton, B. K., \& Morrongiello, B. A. (2011). Examining the impact of traffic environment and executive functioning on children's pedestrian behaviours. Developmental Psychology, 47(1), 182-191.

Barton, B. K., Lew, R., Kovesdi, C., Cottrell, N. D., \& Ulrich, T. (2013). Developmental differences in auditory detection and localization of approaching vehicles. Accident Analysis \& Prevention, 53, 1-8.

Basner, B., \& De Marees, H. (1993). Fahrrad und Straßenverkehrstüchtigkeit von Grundschülern. Gesundheitsschutz in Schule und Beruf Bd. 1. Münster: GUVV-Westfalen-Lippe.

Bächli-Bietry, J. (1998). Konkretisierung eines Ausbildungskonzeptes für Velo- und Mofafahrer an der Oberstufe. bfu-Report. Bern: bfu-Beratungsstelle für Unfallverhütung.

Berger, G. (1992). Entwicklungsphysiologische Komponenten der Unfallverhütung bei Kindern. In U. Schütze (Hrsg.), Freizeitunfälle im Kindes- und Jugendalter (pp. 24-29). Stuttgart, New York: Thieme Verlag. Berk, L. E. (2011). Entwicklungspsychologie. Pearson Deutschland GmbH.

Best, J. R., Miller, P. H., \& Jones, L. L. (2009). Executive functions after age 5: Changes and correlates. Developmental Review, 29(3), 180-200.

Best, J. R., \& Miller, P. H. (2010). A developmental perspective on executive function. Child Development, 81(6), 1641-1660.

Bjorklund, D. F. (2005). Children's Thinking. Cognitive Development and Individual Differences. Belmont: Thomson Wandsworth.

Blades, M., \& Spencer, C. (1985). The use of maps by 4-6-year-old children in a large-scale maze. British Journal of Developmental Psychology, 5(1), 19-24.

Borgert, O., \& Henke, T. (1997). Motorische Radfahrkompetenz von Kindern und Jugendlichen. Gemeindeunfall-Versicherungsverband Westfalen-Lippe, Münster.

Böttcher, A. (2005). Einflüsse von entwicklungspsychologischen Aspekten und der Risikowahrnehmung auf das Verkehrsverhalten von Kindern. Hochschule Magdeburg - Stendal (FH).

Bremner, A. J., Lewkowicz, D. J., \& Spence, C. (2012). Multisensory development. Oxford: University Press.

Briem, V., \& Bengtsson, H. (2000). Cognition and character traits as determinants of young children's behaviour in traffic situations. International Journal of Behavioural Development, 24(4), 492-505.

Brooks, P. J., Hanauer, J. B., Padowska, B., \& Rosman, H. (2003). The role of selective attention in preschoolers' rule use in a novel dimensional card sort. Cognitive Development, 18(2), 195-215.

Brück, J. (2009). Kindersicherheit. Gefahren erkennen, Gefahren vermeiden. Berlin: Beuth Verlag.

Connelly, M. L., Conaglen, H. M., Parsonson, B. S., \& Isler, R. B. (1998). Child pedestrians' crossing gap thresholds. Accident Analysis \& Prevention, 30(4), 443-453.

Cox, M. (1991). The Child's Point of View. (2d Ed.). Hemel Hempstead: Harvester.

Crone, E. (2011). Das pubertierende Gehirn. Wie Kinder erwachsen werden. München: Droemer Verlag.

David, S. S. J., Foot, H. C., Chapman, A. J., \& Sheehy, N. P. (1986). Peripheral vision and the aetiology of child pedestrian accidents. British Journal of Psychology 77(1), 117-135.

Dobson, V., Brown, A. M., Harvey, E. M., \& Narter, D. B. (1998). Visual field extent in children 3.5-30 months of age tested with a double-arc LED perimeter. Vision Research, 38(18), 2743-2760.

Dordel, S., \& Kunz, T. (2005). Bewegung und Kinderunfälle. Chancen motorischer Förderung zur Prävention von Kinderunfällen. München: Gemeindeunfallversicherungsverband Westfalen-Lippe.

Dunbar, G., Lewis, V., \& Hill, R. (1999). Control processes and road-crossing skills. The Psychologist, 12, 398-399.

Dunbar, G., Hill, R., \& Lewis, V. (2001). Children's attentional skills and road behavior. Journal of Experimental Psychology: Applied, 7(3), 227.

Ellemberg, D., Lewis, T. L., Liu, C. H., \& Maurer, D. (1999). Development of spatial and temporal vision during childhood. Vision Research, 39, 2325-2333.

Ellis, J. (2014). Bicycle safety education for children from a developmental and learning perspective (Report No. DOT HS 811 880). Washington, DC: National Highway Traffic Safety Administration.

Finlayson, H. (1972). Children's road behaviour and personality. Transport and Road Research Laboratory. TN 739, Crownthorne.

Flavell, J. H. (1992). Perspectives on perspective taking. In H. Beilin \& P. Pufall (Eds.), Piaget's theory: Prospects and possibilities. Hillsdale, NJ: Erlbaum, 107-139.

Foot, H. C., Thomson, J. A., Tolmie, A. K., Whelan, K. M., Morrison, S., \& Sarvary, P. (2006). Children's understanding of drivers' intentions. British Journal of Developmental Psychology, 24, 681-700.

Funk, W., Hecht, P., Nebel, S., \& Stumpf, F. (2013). Verkehrserziehung in Kindergärten und Grundschulen. Berichte der Bundesanstalt für Straßenwesen, Mensch und Sicherheit, Heft M 238

Gardner, M., \& Steinberg, L. (2005). Peer Influence on Risk Taking, Risk Preference, and Risky Decision Making in Adolescence and Adulthood: An Experimental Study. Developmental Psychology, 41(4), 625-635.
Garon N., Bryson, S. E., \& Smith, I. M. (2008). Executive function in preschoolers: a review using an integrative framework. Psychological Bulletin, 134(1), 31-60.

Gómez-Pérez, E., \& Ostrosky-Solis, F. (2006). Attention and memory evaluation across the life span: heterogeneous effects of age and education. Journal of Clinical and Experimental Neuropsychology, 28(4), 477-494.

Günther, R., \& Limbourg, M. (1977). Dimensionen der Verkehrswelt von Kindern. Bericht der Bundesanstalt für Straßenwesen: Erlebnis- und Verhaltensformen von Kindern im Straßenverkehr, Köln: Reihe Unfall- und Sicherheitsforschung Straßenverkehr, Heft 4, 7-80

Günther, R., \& Degener, S. (2009). Psychomotorische Defizite von Kindern im Grundschulalter und ihre Auswirkungen auf die Radfahr-Ausbildung. Berlin: Gesamtverband der Deutschen Versicherung swirtschaft e.V.

Hargreaves, D. J., \& Davies, G. M. (1996). The development of risk-taking in children. Current Psychology: Developmental, Learning, Personality, Social, 15, 14-29.

Higgins, A. T., \& Turnure, J. E. (1984). Distractibility and concentration of attention in children's development. Child Development, 55, 1799-1810.

Hill, R., Lewis, V., \& Dunbar, G. L. (2000). Young children's concepts of danger. British Journal of Developmental Psychology, 18, 103-119.

Hoffmann, E. R., Payne, A., \& Prescott, S. (1980). Children's estimates of vehicle approach times. Human Factors: The Journal of the Human Factors and Ergonomics Society, 22(2), 235-240.

Hoffmann, J., Martin, C., \& Schilling, A. (2003). Unique transitions between stimuli and responses in SRT tasks: Evidence for the primacy of response predictions. Psychological Research, 67(3), 160-173.

Irwin-Chase, H., \& Burns, B. (2000). Developmental changes in children's abilities to share and allocate attention in a dual task. Journal of Experimental Child Psychology, 77(1), 61-85.

Johnson, S. P., Hannon, E. E., \& Amso, D. (2005). Perceptual development. In B. Hopkins (Ed.), Cambridge Encyclopedia of Child Development (pp. 210-216). Cambridge, UK: Cambridge University Press. Joly, M. F., Foggin, P. M., \& Pless, I. B. (1991). Geographical and socio-ecological variations of traffic accidents among children. Social Science \& Medicine, 33(7), 765-769.

Joshi, M. S., MacLean, M., \& Stevens, C. (2018). Accident frequency and unrealistic optimism: Children's assessment of risk. Accident Analysis \& Prevention, 111, 142-146.

Kambas, A., Antoniou, P., Xanthi, G., Heikenfeld, R., Taxildaris, K. \& Godolias, G. (2004). Unfallverhütung durch Schulung der Bewegungskoordination bei Kindergartenkindern. Deutsche Zeitschrift für Sportmedizin, 55(2), 44-47

Kellmann, P. J., \& Arterberry, M. (2006). Infant visual perception. In D. Kuhn \& R. Siegler (Hrsg.) Handbook of child psychology: Vol. 2, Cognition, perception, and languages (6. Aufl., pp. 109-160). Hoboken, NJ: Wiley.

Klöck, I., \& Schorer, C. (2011). Übungssammlung Frühförderung: Kinder von 0-6 heilpädagogisch fördern. Verlag Reinhardt: München.

Konrad, K., Firk, C., \& Uhlhaas, P. J. (2013). Hirnentwicklung in der Adoleszenz. Neurowissenschaftliche Befunde zum Verständnis dieser Entwicklungsphase. Deutsches Ärzteblatt International, 110(25), 425-431.

Kraebel, K. S., West, R. N., \& Gerhardstein, P. (2007). The influence of training views on infants' longterm memory for simple 3D shapes. Developmental Psychobiology, 49, 406-420.

Küting, H., Boigs, R., \& Winkler, W. (1979). Das Verkehrsverhalten Rad fahrender Kinder und Jugendlicher. Bericht der Bundesanstalt für Straßenwesen, Reihe Unfall- und Sicherheitsforschung Straßenverkehr, Köln. Heft 25.

Lai, Y. H., Wang, H. Z., \& Hsu, H. T. (2011). Development of visual acuity in preschool children as measured with Landolt C and Tumbling E charts. Journal of American Association for Pediatric Ophthalmology and Strabismus \{JAAPOS\}, 15(3), 251-255.

Leat, S. J., Yadav, N. K., \& Irving, E. L. (2009). Development of visual acuity and contrast sensitivity in children. Journal of Optometry, 2(1), 19-26.

Limbourg, M. (1976). Das Verhalten von 4- bis 9-jährigen Kindern bei der Straßenüberquerung. Zeitschrift für experimentelle und angewandte Psychologie, 23, 666-677.

Limbourg, M., \& Senckel, B. (1976). Verhalten von Kindern als Fußgänger im Straßenverkehr. Bericht der Bundesanstalt für Straßenwesen. Köln.

Limbourg, M., Höpfner, S., \& Niebling, C. (1977). Die Stabilität des Verhaltens von 4- bis 9-jährigen Kindern bei der Straßenüberquerung. Zeitschrift für Verkehrserziehung, 3, 3-8.

Limbourg, M. (1995). Kinder im Straßenverkehr. Münster: GUVV-Westfalen-Lippe.

Limbourg, M. (1997). Kinder unterwegs im Verkehr - Ansätze zur Erhöhung der Verkehrssicherheit im Kindes- und Jungendalter. Verkehrswachtforum, Heft 3, Meckenheim.

Limbourg, M. (2001). Mobilitäts-/Verkehrserziehung als Aufgabe der Grundschule. Retrieved from http://duepublico.uni-duisburg-essen.de/servlets/DerivateServlet/Derivate-11652/VE_Sache_Wort_ Zahl01.pdf

Limbourg, M. (2003). Psychologische Grundlagen der Lern- und Leistungsmöglichkeit von Kindern im Straßenverkehr. Vortrag beim 39. Deutschen Verkehrsgerichtstag 2001 in Goslar., Deutsche Akademie für Verkehrswissenschaft. Hamburg, 2001, 39-50.

Limbourg, M. (2008). Kinder unterwegs im Straßenverkehr. Prävention in NRW 12. Düsseldorf: Unfallkasse Nordrhein-Westfalen.

Limbourg, M. (2010). Kinder unterwegs im Straßenverkehr. Prävention in NRW 12. Düsseldorf: Unfallkasse Nordrhein-Westfahlen.

Luna, B., Tholborn, K. R., Munoz, D. P., Merriam, E. P., Garver, K. E., Minshew, N. J., ... Sweeney, J. A. (2001). Maturation of Widely Distributed Brain Function Subserves Cognitive Development. Neurolmage, 13, 786-793.

Martin, L. (2010). Development of the visual field. In G. Lennerstrand \& G. Öyvist Seimyr (Eds.), Advances in pediatric ophthalmology research (pp. 25-32). Stockholm: The Sigvard \& Mariann Bernadotte Research Foundation for Children Eye Care.

Meir, A., Parmet, Y., \& Oron-Gilad, T. (2013). Towards understanding child-pedestrians' hazard perception abilities in a mixed reality dynamic environment. Transportation Research Part F: Traffic Psychology and Behaviour, 20, 90-107. 


\section{References to Table 1}

Meir, A., Oron-Gilad, T., \& Parmet, Y. (2015a). Can child-pedestrians' hazard perception skills be enhanced? Accident Analysis \& Prevention, 83, 101-110.

Meir, A., Oron-Gilad, T., \& Parmet, Y. (2015b). Are child-pedestrians able to identify hazardous traffic situations? Measuring their abilities in a virtual reality environment. Safety Science, 80, 33-40.

Michaelis, R., \& Niemann, G. (1999). Entwicklungsneurologie und Pädiatrie. 2. Auflage. Thieme, Stuttgart. Miller, P. H., \& Weiss, M. G. (1981). Children's attention allocation, understanding of attention, and performance on the incidental learning task. Child Development, 52(4), 1183-1190.

Morrongiello, B. A., Corbett, M., Milanovic, M., Pyne, S., \& Vierich, R. (2015). Innovations in using virtual reality to study how children cross streets in traffic: evidence for evasive action skills. Injury Prevention, 21, 266-270.

Nougier, V., Bard, C., Fleury, M., \& Teasdale, N. (1998). Contribution of central and peripheral vision to the regulation of stance: developmental aspects. Journal of Experimental Child Psychology, 68, 202-215.

O'Neal, E. E., Jiang, Y., Franzen, L. J., Rahimian, P., Yon, J. P., Kearney, J. K., \& Plumert, J. M. (2018). Changes in perception-action tuning over long time scales: How children and adults perceive and act on dynamic affordances when crossing roads. Journal of Experimental Psychology: Human Perception and Performance, 44(1), 18

Oron-Gilad, T., Meir, A., Tapiro, H., \& Borowsky, A. (2011). Towards understanding child-pedestrian's deficits in perceiving hazards when crossing the road, final report. Negev: Ben-Gurion University, Human Factors Engineering Laboratory.

Passarotti, A. M., Sweeney, J. A., \& Pavuluri, M. N. (2009). Neural correlates of incidental and directed facial emotion processing in adolescents and adults. Social Cognitive and Affective Neuroscience, 4(4), 387-398.

Pastò, L., \& Burack, J. A. (1997). A developmental study of visual attention: Issues of filtering efficiency and focus. Cognitive Development, 12, 523-535.

Pearson, D. A., \& Lane. D. M. (1990). Visual attention movements: A developmental study. Child Development, 61, 1779-1795.

Percer, J. (2009). Child Pedestrian Safety Education. Applying Learing and Developmental Theories to Develop Safe Street-Crossing Behaviours. Washington DC: U. S. Department of Transportation. National Highway Traffic Safety Administration.

Pettit, F., \& Janks, A. (1996). Children's competence as road users: The relevance of child development theory and research. Haymarket, NSW: Road Safety and Traffic Management Directorate, Roads and Traffic Authority.

Pfafferott, I. (1994). Straßengestaltung im Interesse von Kindern. In A. Flade (Hrsg.), Mobilitätsverhalten: Bedingungen und Veränderungsmöglichkeiten aus umweltpsychologischer Sicht (pp. 291-304). Weinheim: Psychologie Verlags Union.

Pfeffer, K., \& Barnecutt, P. (1996). Children's auditory perception of movement of traffic sounds. Child: Care, Health and Development, 22(2), 129-137.

Piaget, J. (1983). Meine Theorie der geistigen Entwicklung. Frankfurt: Fischer-Verlag.

Pieper, W. (1990). Entwicklung der Wahrnehmung. In H. Hetzer, E. Todt, I. Seiffge-Krenke \& R. Arbinger (Hrsg.), Angewandte Entwicklungspsychologie des Kindes- und Jugendalters (pp. 19-46). Heidelberg: Quelle \& Meyer.

Pitcairn, T. K., \& Edlmann, T. (2000). Individual differences in road crossing ability in young children and adults. British Journal of Psychology, 91, 391-410.

Platho, C., Paulenz, A., \& Kolrep, H. (2016). Wahrnehmungspsychologische Analyse der Radfahraufgabe. Berichte der Bundesanstalt für Straßenwesen, Mensch und Sicherheit, Heft M 267, Bergisch Gladbach. Plumert, J. M. (1995). Relations between children's overestimation of their physical abilities and accident proneness. Developmental Psychology, 31, 866-876.

Plumert, J. M., Kearney, J. K., \& Cremer, J. F. (2004). Children's perception of gap affordances: Bicycling across traffic-filled intersections in an immersive virtual environment. Child Development, 75(4), 1243-1253.

Plumert, J. M., Kearney, J. K., \& Cremer, J. F. (2007). Children's road crossing. A window into perceptualmotor development. Current Directions in Psychological Science, 16(5), 255-258.

Plumert, J. M., Kearney, J. K., Cremer, J. F., Recker, K. M., \& Strutt, J. (2011). Changes in children's perception-action tuning over short time scales: Bicycling across traffic-filled intersections in a virtual environment. Journal of Experimental Child Psychology, 108(2), 322-337.

Premack, D., \& Woodruff, G. (1978). Does the chimpanzee have a theory of mind? Behavioural and Brain Sciences, 1(4), 515-526.

Richter, S., Gruner, E.-M., Rollow, A., \& Schneiders, W. (2006). Epidemiologie von Kindern und Jugendlichen im Untersuchungsgebiet. In B. Schlag, D. Rösner, H. Zwipp \& S. Richter (Hrsg.), Kinderunfälle - Ursachen und Prävention (pp. 12-24). Wiesbaden: VS Verlag für Sozialwissenschaften.

Richter, S., Schlag, B., \& Schupp, A. (2006). Zum Einfluss entwicklungspsychologischer Besonderheiten des Kindes- und Jugendalters auf die Unfallgefährdung. In B. Schlag, D. Rösner, H. Zwipp \& S. Richter (Hrsg.) Kinderunfälle - Ursachen und Prävention (pp. 25-35). Wiesbaden: VS Verlag für Sozialwissenschaften.

Ristic, J., \& Kingstone, A. (2009). Rethinking attentional development: reflexive and volitional orienting in children and adults. Developmental Science, 12(2), 289-296.

Rollett, B. (1993). Zur Entwicklung des Sicherheitsbewusstseins bei Kindern und Jugendlichen. In L. Montada (Hrsg.), Bericht über den 38. Kongress der deutschen Gesellschaft für Psychologie in Trier 1992. (Band 2, pp. 271-276). Göttingen: Hogrefe.

Rosenbloom, T., Nemrodov, D., Ben-Eliyahu, A., \& Eldror, E. (2008). Fear and danger appraisals of a road-crossing scenario: A developmental perspective. Accident Analysis \& Prevention, 40(4), 1619-1626. Savelsbergh, G., Davids, K., van der Kamp, J., \& Bennett, S. J. (2003). Development of movement co-ordination in children. Applications in the fields of ergonomics, health sciences and sport. London: Routledge. Schieber, R. A., \& Thompson, N. J. (1996).Developmental risk factors for childhood pedestrian injuries. Injury Prevention, 2(3), 228-236

Schneider, C. M. (2001). Eine Analyse von Kinder- und Jugendunfällen unter Berücksichtigung von Alter und Kognition. In: B. Schlag \& S. Richter (2004). Unfallprävention - Verkehrssicherheit. In: B. Schlag (Hrsg), Verkehrspsychologie: Mobilität - Sicherheit - Fahrerassistenz. Legerich: Pabst.

Schneider, W., \& Lindenberger, U. (2012). Entwicklungspsychologie. 7. Auflage. Weinheim, Basel: Beltz. Schützhofer, B. (2017). Verkehrsreife - Theoretische Fundierung, Entwicklung und Erprobung der Testbatterie zur Erfassung der Verkehrsreife TBVR 14+. Bonn: Kirschbaum Verlag GmbH.
Schützhofer, B., Rauch, J., \& Banse, R. (2017). Verkehrssicherheitsarbeit mit Jugendlichen an der Schwelle zur motorisierten Straßenverkehrsteilnahme - welchen Beitrag kann die Verkehrspsychologie dazu leisten? Zeitschrift für Verkehrssicherheit, 63(5), 215-224.

Schwebel, D. C., \& Plumert, J. M. (1999). Longitudinal and concurrent relations between temperament, ability estimation, and injury proneness. Child Development, 70, 700-712.

Schwebel, D. C., Davis, A. L., \& O'Neal, E. E. (2012). Child pedestrian injury: A review of behavioural risks and preventive strategies. American Journal of Lifestyle Medicine, 6(4), 292-302.

Siegler, R. S., \& Richards, D. D. (1979). Development of time, speed, and distance concepts. Developmental Psychology, 15(3), 288-298.

Slater, A. (2001). Visual perception. In G. Bremner \& A. Fogel (Ed.). Blackwell handbook of infant development (pp. 5-34). Malden, MA: Blackwell.

Steinberg, L. (2008). A Social Neuroscience Perspective on Adolescent Risk-Taking. Developmenta Review, 28(1), 78-106.

Stevens, E., Plumert, J. M., Cremer, J. F., \& Kearney, J. K. (2013). Preadolescent temperament and risky behaviour: bicycling across traffic-filled intersections in a virtual environment. Journal of Pediatric Psychology, 38(3), 285-295.

Tabibi, Z., \& Pfeffer, K. (2003). Choosing a safe place to cross the road: the relationship between attention and identification of safe and dangerous road-crossing sites. Child: Care, Health and Development, 29(4), 237-244.

Tapiro, H., Oron-Gilad, T., \& Parmet Y. (2016). Cell phone conversations and child pedestrian's crossing behavior; a simulator study. Safety Science, 89, 36-44.

Tharpe, A. M., \& Ashmead, D. H. (2001). A longitudinal investigation of infant auditory sensitivity. American Journal of Audiology, 10(2), 104-112.

Thompson, J. A. (1997). Developing safe route planning strategies in young child pedestrians. Journal of Applied Developmental Psychology, 18(2), 271-281.

Tolmie, A., Thomson, J. A., Foot, H. C., Whelan, K., Morrison, S., \& McLaren, B. (2005). The effects of adult guidance and peer discussion on the development of children's representations: Evidence from the training of pedestrian skills. British Journal of Psychology, 96, 181-204.

Trick, L. M., \& Enns, J. T. (1998). Lifespan changes in attention: The visual search task. Cognitive Development, 13, 369-386.

Uhr, A. (2015). Entwicklungspsychologische Grundlagen. Überblick und Bedeutung für die Verkehrssicherheit. Bern: bfu-Beratungsstelle für Unfallverhütung.

Uhr, A. Allenbach, R., Ewert, U., Niemann, S., Hertach, P., Achermann Stürmer, Y., \& Cavegn, M. (2017). Sicherheit von Kindern im Strassenverkehr. Bfu-Sicherheitsdossier Nr. 16. Bern: bfu-Beratungsstelle für Unfallverhütung.

Underwood, J., Dillon, G., Farnsworth, B., \& Twiner, A. (2007). Reading the road: the influence of ag and sex on child pedestrians' perceptions of road risk. British Journal of Psychology, 98(1), 93-110. Van der Molen, H. H. (2002). Young pedestrians and young cyclists. In R. Fuller \& J. A. Santos (Eds.), Human Factors for Highway Engineers (pp. 217-240). Oxford: Pergamon.

Walesa, C. (1975). Children's approaches to chance- and skill-dependent risk. Polish Psychological Bulletin, 6, 131-138.

Walter, E., Achermann Stürmer, Y., Scaramuzza, G., Niemann, S., \& Cavegn, M. (2012). Fahrradverkehr. Bfu-Sicherheitsdossier, 8. Bern: bfu.

Walter, E., Achermann Stürmer, Y., Scaramuzza, G., Niemann, S., \& Cavegn, M. (2013). Fußverkehr. Bfu-Sicherheitsdossier Nr. 11. Bern: bfu.

Wann, J. P., Poulter, D. R., \& Purcell, C. (2011). Reduced sensitivity to visual looming inflates the risk posed by speeding vehicles when children try to cross the road. Psychological Science, 22(4), 429-434.

Warwitz, S. (2009). Verkehrserziehung vom Kinde aus. Hohengehren: Schneider Verlag.

Weber, K., Van Betuw, A., Braun, E., Caraben, A., Gregerson, N. P., Hellstein, H. ... Vissers, J. (2005). ROSE 25 - Inventory and compiling of a European good practice guide on road safety education targeted at young people. Wien: Kuratorium für Verkehrssicherheit.

Welsh, M. C., Pennington, B. F., \& Groisser, D. B. (1991). A normative developmental study of executive function: A window on prefrontal function in children. Developmental Neuropsychology, 7(2), 131 149

\section{Werner, L. A., \& Marean, G. C. (1996). Human auditory development. Springer.}

Werner L. A., \& Gray, L. (1998). Behavioral studies of human development. In E. W. Rubel, A. N. Popper, \& R.R. Fay (Eds.), Springer Handbook of Auditory Research. Vol. IX: Development of the Auditory System (pp. 12-79). New York: Springer.

Westenberg. P.M. \& Gjerde P.F. (1999). Ego Development during the Transition from Adolescence to Young Adulthood: A 9-Year Longitudinal Study. Journal of Research in Personality, 33, 233-252.

Whitebread, D., \& Neilson, K. (2000). The contribution of visual search strategies to the development of pedestrian skills by 4 to 11 year-old children. British Journal of Educational Psychology, 70(4), 539-557.

Wildner M. Heissenhuber A. \& Kuhn, J. (2009). Unfälle im Kindesalter In E. M. Bitzer, U. Walter, H. Lingner \& F.-W. Schwartz (Hrsg.), Kindergesundheit stärken - Vorschläge zur Optimierung von Prävention und Versorgung (pp. 210-219). Berlin - Heidelberg: Springer-Verlag.

Wimmer, H.. \& Perner, J. (1983). Beliefs about beliefs: representations and constraining functions of wrong beliefs in young children's understanding of deception. Cognition, 13, 103-128.

Young, D. S., \& Lee, D. N. (1987). Training children in road crossing skills using a roadside simulation. Accident Analysis \& Prevention, 19(5), 327-341.

Zeedyk, M. S., Wallace, L., \& Spry, L. (2002). Stop, look, listen, and think?: What young children really do when crossing the road. Accident Analysis \& Prevention, 34(1), 43-50.

Zeuwts, L., Vansteenkiste, P., Cardon, G., \& Lenoir, M. (2016). Development of cycling skills in 7-to 12-year-old children. Traffic Injury Prevention, 17(7), 736-742.

Zeuwts, L. H., Vansteenkiste, P., Deconinck, F. J., Cardon, G., \& Lenoir, M. (2017). Hazard perception in young cyclists and adult cyclists. Accident Analysis \& Prevention, 105, 64-71. 